\title{
Manuscript Details
}

\section{Manuscript number}

Title

Article type
MARGO_2018_155_R1

Coupling between tidal mudflats and salt marshes affects marsh morphology

\section{Abstract}

It is generally assumed that coastal salt marshes are capable of adapting to moderately fast rising sea levels although local sediment availability crucially affects this capability. Whilst there is an increasing awareness that the local sediment availability is inherently related to sediment dynamics on the adjacent tidal mudflat, our current understanding of the interactions between salt marshes and tidal flats is very limited. To address this knowledge gap, we measured suspended sediment concentrations alongside hydrodynamic, morphological and sediment deposition measurements over a total period of 16 weeks in a wave-exposed macro-tidal mudflat-salt marsh system on the UK east coast (Tillingham). Our results show that local sediment supply to the salt marsh is strongly linked to intertidal sediment dynamics and that the vast majority of suspended sediment deposited on the marsh originates from windwave induced intertidal sediment resuspension in very close vicinity $(<130 \mathrm{~m})$ to the seaward marsh margin. Vertically the salt marsh grows at rates $>5 \mathrm{~mm} y \mathrm{r}-1$, thereby increasing the slope of the tidal mudflat-salt marsh transition and making the salt marsh susceptible to lateral erosion. Consequently, the marsh edge retreats at a rate of approximately $0.8 \mathrm{~m}$ yr-1. Our study shows that the response of coastal salt marshes to climate change is a function of the coupled tidal mudflat-salt marsh system, rather than their vertical sediment accretion rates alone. Therefore, the idea that salt marsh adaptability relies on local sediment supply needs to be expanded, incorporating the morphology and long-term evolution of the adjacent tidal mudflats.

\section{Keywords}

Taxonomy

Corresponding Author

Corresponding Author's Institution

Order of Authors

Suggested reviewers
Salt marsh, tidal mudflat, sediment deposition, intertidal sediment resuspension, lateral marsh erosion, wave activity

Salt Marsh, Coastal Process, Intertidal Zone, Geomorphic Change, Erosional Process

Mark Schuerch

University of Cambridge

Mark Schuerch, Tom Spencer, Ben Evans

Ya Ping Wang, Daninka van Proosdij, Rusty Feagin, Nathaniel Weston, Tom Ysebaert, Zeng Zhou 


\section{Coupling between tidal mudflats and salt marshes affects marsh}

\section{morphology}

1 Mark Schuerch ${ }^{1,2^{*}}$, Tom Spencer ${ }^{2}$, Ben Evans ${ }^{2}$

$2 \quad{ }^{1}$ Lincoln Centre for Water and Planetary Health, School of Geography, University of

3 Lincoln, Brayford Pool Campus, Lincoln, United Kingdom

$4 \quad{ }^{2}$ Cambridge Coastal Research Unit, Department of Geography, University of Cambridge,

5 Downing Place, Cambridge, United Kingdom

6 * Correspondence:

7 mschuerch@lincoln.ac.uk

8 Abstract

9 It is generally assumed that coastal salt marshes are capable of adapting to moderately fast

10 rising sea levels although local sediment availability crucially affects this capability. Whilst

11 there is an increasing awareness that the local sediment availability is inherently related to

12 sediment dynamics on the adjacent tidal mudflat, our current understanding of the

13 interactions between salt marshes and tidal flats is very limited. To address this knowledge

14 gap, we measured suspended sediment concentrations alongside hydrodynamic,

15 morphological and sediment deposition measurements over a total period of 16 weeks in a

16 wave-exposed macro-tidal mudflat-salt marsh system on the UK east coast (Tillingham).

17 Our results show that local sediment supply to the salt marsh is strongly linked to intertidal

18 sediment dynamics and that the vast majority of suspended sediment deposited on the marsh 
19 originates from wind-wave induced intertidal sediment resuspension in very close vicinity $(<$

$20130 \mathrm{~m}$ ) to the seaward marsh margin. Vertically the salt marsh grows at rates $>5 \mathrm{~mm} \mathrm{yr}^{-1}$,

21 thereby increasing the slope of the tidal mudflat-salt marsh transition and making the salt

22 marsh susceptible to lateral erosion. Consequently, the marsh edge retreats at a rate of

23 approximately $0.8 \mathrm{~m} \mathrm{yr}^{-1}$. Our study shows that the response of coastal salt marshes to climate

24 change is a function of the coupled tidal mudflat-salt marsh system, rather than their vertical

25 sediment accretion rates alone. Therefore, the idea that salt marsh adaptability relies on local

26 sediment supply needs to be expanded, incorporating the morphology and long-term

27 evolution of the adjacent tidal mudflats.

\section{Keywords}

29 Salt marsh, tidal mudflat, sediment deposition, intertidal sediment resuspension, lateral 30 marsh erosion, wave activity

\section{$31 \quad 1 \quad$ Introduction}

32 Coastal salt marshes are increasingly considered as valuable ecosystems at the interface

33 between land and sea; they are known to sequester atmospheric carbon, contribute to global

34 biodiversity, improve coastal water quality, and provide protection against coastal flooding

35 and erosion (Barbier et al., 2011). Under ongoing global sea level rise (SLR; Church et al.,

36 2013) concerns have been expressed, first voiced by Stevenson et al. (1986), that coastal salt

37 marshes may experience 'accretionary deficit' (i.e. not being able to sufficiently adapt their

38 elevation through vertical sediment accretion), become inundated permanently and convert

39 to open water (Crosby et al., 2016; Spencer et al., 2016; Schepers et al., 2017). However, the

40 increase in surface elevation, particularly of minerogenic coastal salt marshes (i.e. salt 
41 marshes 'dominated by tidally introduced mineral matter' (Allen, 2000)), is driven by the

42 deposition of suspended sediment during inundation events. This process may accelerate

43 under increased rates of SLR and associated higher inundation frequencies (Kolker et al.,

44 2010; Hill and Anisfeld, 2015). The environmental variables primarily controlling the ability

45 of minerogenic coastal salt marshes to vertically adapt to SLR are commonly assumed to be

46 local tidal range, sediment availability and inundation frequency (French, 1993; French,

47 2006; Kirwan et al., 2010; D'Alpaos et al., 2011; Schuerch et al., 2013; Schuerch et al., 2018).

48 It has been variously hypothesised that increased local tidal range will (i) increase sediment

49 resuspension through higher tidal current velocities, hence improving sediment availability

50 (Friedrichs and Perry, 2001; Temmerman et al., 2003; Schuerch et al., 2013); (ii) reduce

51 SLR-induced channel erosion, due to a proportionally smaller increase of the tidal prism

52 (Kirwan and Guntenspergen, 2010); and (iii) increase the elevation range where salt marsh

53 vegetation can grow (Friedrichs and Perry, 2001; Kirwan and Guntenspergen, 2010). Greater

54 sediment availability, seen in higher suspended sediment concentrations (SSCs), will

55 increase the amount of mineral sediment being deposited on the marsh surface during a single

56 inundation (French, 1993; French, 2006; Kirwan and Murray, 2007), assuming an invariant

57 sediment trapping efficiency (i.e. 'percentage of the sediment introduced on flood tide

58 retained on the marsh surface' (French, 2006: p. 127)). Finally, it can be argued that if the

59 marsh is inundated more regularly, sediment deposition events will become more frequent

60 and thus the rate of sedimentation will increase.

61 Supply of suspended sediment for coastal salt marshes is highly variable in space and time,

62 owing to the multitude of processes involved in coastal sediment transport and sediment

63 resuspension (Wang et al., 2012), as well as the large variability associated with 
64 meteorological and climate drivers (Schuerch et al., 2016; Zhou et al., 2016; Ma et al., 2018).

65 Despite knowledge about the crucial importance of sediment supply and its pronounced

66 temporal variability for minerogenic marshes, most model-based assessments on the ability

67 of coastal wetlands to adapt to future SLR assume a constant sediment supply (French, 1993;

68 French, 2006; Mariotti and Fagherazzi, 2010; D'Alpaos et al., 2011; Mariotti and Carr, 2014;

69 Rodríguez et al., 2017). Where temporal variations in sediment supply are accounted for,

70 sediment supply is assumed to be driven by current-induced intertidal sediment resuspension

71 (Temmerman et al., 2003; D'Alpaos et al., 2007; Schuerch et al., 2013). However, other

72 studies have suggested that wave-induced sediment resuspension may be more important for

73 marsh sediment supply (Callaghan et al., 2010; Ma et al., 2018) but field data on how wave-

74 induced sediment resuspension affects the morphological development of salt marshes are

75 rare. Furthermore, in order to improve our understanding of the impacts that temporal

76 variations in sediment supply may have on the ability of coastal salt marshes to adapt to

77 future SLR, exact knowledge on the sources of the supplied sediment is necessary, including

78 the relative contributions from both wave- and current-induced sediment resuspension

79 (Schuerch et al., 2014).

80 It has previously been argued that the sources of mineral suspended sediment supplied to a

81 salt marsh can broadly be divided into external ('far field') and proximate ('near field')

82 sediment sources (Schuerch et al., 2014). External sediment sources include contributions

83 from riverine sediment discharge (Bergamino et al., 2017), coastal erosion along

84 neighbouring coastlines, offshore sediment sources and atmospheric deposition (Pedersen

85 and Bartholdy, 2006; Schuerch et al., 2014; Schuerch et al., 2016). Proximate sediment

86 sources include sediment resuspension on tidal mudflats and erosion of marsh cliffs and tidal 
87 creeks (Friedrichs and Perry, 2001; Pedersen and Bartholdy, 2006; Mariotti and Carr, 2014;

88 Schuerch et al., 2014).

89 The aim of this study was to identify the role of intertidal sediment resuspension in

90 contributing sediment to a salt marsh on the UK east coast from an adjacent, proximate

91 mudflat. Further, we aimed to identify the drivers of temporal variations in intertidal sediment

92 resuspension, particularly focusing on changes in hydrodynamic and meteorological

93 conditions, and to assess how these variations influence sediment deposition processes on

94 the marsh platform. More specifically, the research questions to be answered include: (i) what

95 are the drivers for the temporal variability in sediment supply?; (ii) how does this observed

96 temporal variability affect sediment deposition patterns on the salt marsh platform?; and (iii)

97 what are the implications of the observed temporal variability for the long-term

98 morphological development of the salt marsh?

\section{$99 \quad 2 \quad$ Regional Setting}

100 The study site is a macro-tidal salt marsh on the UK east coast between the Blackwater and 101 the Crouch estuaries (Dengie Peninsula) on the northern margin of the Greater Thames

102 Estuary, near the village of Tillingham (Fig. 1). The mean spring tidal range is $4.8 \mathrm{~m}$, and the 103 neap tidal range $2.9 \mathrm{~m}$ (Towler and Fishwick, 2017). This open coast marsh is exposed to a 104 moderate wave climate with a mean significant wave height of $0.18 \mathrm{~m}$ and a maximum 105 significant wave height of $0.73 \mathrm{~m}$ (October 2012 - July 2016), as measured at the marsh edge 106 (unpublished data).

107 The salt marsh is located to seaward of an earthen embankment (seawall) and has varying 108 widths of up to $700 \mathrm{~m}$. Adjacent to the vegetated marsh platform, an extensive tidal mudflat 
109 extends into the North Sea for up to $3.7 \mathrm{~km}$ offshore (Möller, 2006). The transition zone from

110 tidal mudflat to vegetated salt marsh is characterised by a shore-normal system of ridges and

111 runnels (Fig. 2). The elevations of the marsh platform range from $1.9 \mathrm{~m}$ in the pioneer

112 vegetation zone to $2.5 \mathrm{~m}$ above Ordnance Datum Newlyn (ODN; where 0.0 ODN

113 approximates mean sea level) in the mid and high marsh vegetation zones (Fig. 2).

\section{Materials and Methods}

\section{$115 \quad 3.1 \quad$ Experimental setup}

116 Field measurements of the hydrodynamics and the morphological development of the tidal

117 mudflat; SSCs along a $177 \mathrm{~m}$ long, shore-normal transect; and sediment deposition on the

118 marsh platform were conducted over a 5-week period in summer (25/05 - 28/06/2016) and

119 an 11-week period in autumn/winter (20/09 - 06/12/2016). The most seaward-located

120 measuring station was $130 \mathrm{~m}$ from the edge of the vegetated marsh platform (marsh edge) on

121 the tidal mudflat (ASM2113). The most landward location was situated in the mid marsh

122 vegetation zone (a mixed canopy dominated by Puccinellia maritima), $47 \mathrm{~m}$ inland from the

123 marsh edge and $210 \mathrm{~m}$ seaward of the seawall (Fig. 2).

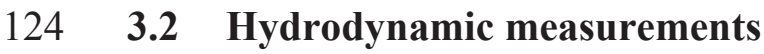

125 Water levels along the entire transect were measured using four pressure sensors (Solnist 126 Levellogger, Model 3001), programmed to record water levels every 30 seconds (Fig. 2).

127 The measured raw data from the pressure sensors were corrected for variations in 128 atmospheric pressure and smoothed with a 15-min moving average filter to derive still water 129 levels, maximum inundation depths of tidal inundations (HW levels), tidal asymmetry (i.e. 
130 ebb duration/flood duration) and the frequency of inundation of the marsh surface at the

131 marsh edge (ASM2115). Based on the unsmoothed water levels, and using the method of

132 Reef et al. (2018), the temporal variability in wave activity during the experiment was

133 approximated with a wave proxy, calculated as the tide-averaged absolute water level

134 deviations from the still water level.

135 The data collected at a recording frequency of $4 \mathrm{~Hz}$ by the bottom-mounted PDCR 1830

136 pressure transmitter (GE Druck) during the high-water stages of selected tidal inundations

137 (Fig. 2) were processed to produce summary wave parameters, following the methodology

138 of Möller et al. (1999). From these wave parameters, the root mean square wave height $\left(H_{r m s}\right)$

139 was used to calibrate the wave proxy. The calibration showed that the wave proxy (WP),

140 calculated at ASM2113, was linearly correlated with $H_{r m s}$, recorded by the PDCR 1830. The

141 linear regression showed that $H_{r m s}=6.645 * W P\left(\mathrm{R}^{2}=0.93\right)$, as reported by Reef et al. (2018).

142 Tidal currents were measured on the tidal mudflat at ASM2113, using an Acoustic Doppler

143 Current Profiler (ADCP), namely an Aquadopp Profiler $2 \mathrm{MHz}$ (Nortek AS), with a recording

144 interval of $30 \mathrm{~s}$. Various measurement settings were tested to optimize the measurement

145 accuracy and precision, including cell size and measurement load (ping rate). The resulting

146 measurement precision typically ranged between 1 and $2 \mathrm{~cm} \mathrm{~s}^{-1}$ with a nominal accuracy of

$147 \quad 0.5 \mathrm{~cm} \mathrm{~s}^{-1}$ (Nortek technical specification).

\section{$148 \quad 3.3 \quad$ Turbidity measurements}

149 Turbidity measurements were conducted using two turbidity profilers, namely two Argus

150 Suspension Meters (ASM) IV (ARGUS Gesellschaft für Umweltmeßtechnik mbH). The

151 profilers consist of 144 optical backscatter sensors, arranged as a vertical array with a spacing 
152 of $1 \mathrm{~cm}$. One turbidity profiler (ASM2113) was deployed on the mudflat (130 m from the

153 marsh edge); the other (ASM2115) was located in the transition zone between the annual

154 pioneer vegetation and the perennial marsh vegetation, the boundary defined as the marsh

155 edge for the purpose of this experiment (Fig. 2). Data were recorded every 30 seconds,

156 averaging 10 measurements at $1 \mathrm{~Hz}$ within $10 \mathrm{~s}$. All measurements were discarded when

157 inundation depths were lower than $3 \mathrm{~cm}$.

158 Conversion of the turbidity data ( $\mathrm{ftu})$ to $\mathrm{SSC}\left(\mathrm{mg} \mathrm{l}^{-1}\right)$ was performed based on 53 1-litre water

159 samples, collected with an automated water sampler (Teledyne ISCO, model 6712) during

160 three time periods in April (7 - 11), July (21 - 24) and December (12 - 17) 2016. Water

161 samples were filtered using pre-weighed $\mathrm{GF} / \mathrm{C}$ filters, dried at $105^{\circ} \mathrm{C}$ for 24 hours and

162 subsequently re-weighed. For the 5-week measurement period in summer, the SSCs derived

163 from 34 water samples from April and July were used for the instrument calibration (Reef et

164 al., 2018); for the autumn and winter measurement period, the SSCs derived from 19 water

165 samples from December were utilized (unpublished data).

$166 \quad 3.4$ Measurements of sediment deposition on the salt marsh surface and elevation 167 change

168 Sediment deposition was measured using filter traps, deployed on the marsh surface at three

169 different locations along a cross-shore transect, starting from the landward turbidity profiler

170 (ASM2115) and proceeding in a landward direction (Fig. 2). During the summer period, 171 measurements were conducted at the sites ASM2115, P4 and SET1, whereas during the

172 autumn/winter period, the site SET1 was exchanged for SET2 (Fig. 2). At each location, three

173 filter traps were installed to capture the small-scale spatial variability in deposition and to 
174 derive an average local deposition. The filter traps consisted of pre-weighed glass-fibre filters

175 (Whatman GF/F) with a diameter of $9 \mathrm{~cm}$, being placed on an equally sized petri dish and

176 fixed with three metal pegs (Nolte et al., 2013). Following their deployment, the filter traps

177 were usually retrieved after five days, although retrievals varied between two and ten days.

178 Alongside the transect of filter traps, a Rod Surface Elevation Table (RSET; Cahoon et al., 179 2002), was used in combination with feldspar marker horizons (MH) at two different sites 180 (SET1 and SET2, figure 2) to monitor surface elevation changes and sediment accretion rates 181 between December 2015 and February 2017, with measurements on 18 December 2015, 11 182 July 2016 and 17 February 2017. In contrast to the filter traps, the coupled RSET and MH 183 method reveals the longer-term salt marsh surface elevation change and near-surface vertical 184 accretion rate respectively (Cahoon et al., 1995). Average surface elevations and standard 185 deviations were calculated from 36 measurements for each RSET site, consisting of nine 186 measurements at four locations around the site. Similarly, average accretion rates and 187 standard deviations were calculated from $12 \mathrm{MH}$ measurements per site, namely three 188 replicates at four locations around the site (same locations as used for the RSET 189 measurements).

\section{$190 \quad 3.5 \quad$ Measurement of mudflat surface elevation}

191 The sediment dynamics on the tidal mudflat were monitored using coloured sand tracer sticks 192 that were vertically inserted into the mudflat, until the upper end of the column was level 193 with the mudflat surface. The tracer sticks ( $88 \mathrm{~mm}$ in length, $10-20 \mathrm{~mm}$ in width, $5-10 \mathrm{~mm}$ 194 in thickness) consisted of a mixture of coloured sand and a highly concentrated sugar 195 solution, which were "baked" in a plastic tray for three days at $50^{\circ} \mathrm{C}$. Upon insertion into the 
196 mudflat, the solidified sand tracers, cemented by the sugar solution, dissolved as the sugar

197 solution dissolved in the water-saturated sediment, and the coloured sand was left as an

198 indicator for sediment mobilization and deposition (Runte, 1989; Schwarzer et al., 2003). In

199 contrast to the tidal mudflat under investigation, the tracer sticks consisted of non-cohesive

200 sand particles to ensure rapid dissolution of the binding material (the sugar solution).

201 Meanwhile, the effect of the potentially higher erodibility is of the tracer stick material was

202 counteracted by the small width and thickness of the tracer stick.

203 After five days (occasionally two or ten days), a $20 \mathrm{~cm}$ long sediment core was extracted at

204 each tracer location, using a PVC tube with an inner diameter of $7.0 \mathrm{~cm}$, to retrieve the

205 remaining tracer stick. In the laboratory, each core was opened through its centre to measure

206 the remaining length of the tracer stick (L) as well as the thickness, if any, of the sediment

207 layer deposited above the tracer $(\mathrm{T})$. . The net erosion $(E=$ negative $)$ or deposition $(E=$ 208 positive) was calculated based on the initial length of the tracer stick $(I L): E=I L-(L+T)$.

\section{$209 \quad 3.6 \quad$ Meteorological data}

210 Meteorological data (recorded wind speeds and wind directions) for the time period of the

211 experiment were obtained from the weather station at Shoeburyness, Thames Estuary (Met

212 Office, 2006), $17 \mathrm{~km}$ SE of the study site (Fig. 1). It was assumed that the study site was

213 exposed to the same wind condition as at Shoeburyness.

\section{$214 \quad 3.7 \quad$ Long-term marsh edge dynamics}

215 The overall change in marsh edge position was determined for the time period 1992 to 2013

216 over the $11 \mathrm{~km}$ long eastward facing edge of the Dengie Peninsula that is fronted by marsh. 
217 The seaward limit of macrophytic vegetation was manually digitised from UK Environment

218 Agency vertical aerial photography for both years $(25 \mathrm{~cm}$ resolution panchromatic in 1992

219 and $20 \mathrm{~cm}$ RGB in 2013, late summer acquisitions). The Digital Shoreline Analysis System

220 (DSAS; Thieler et al., 2009) was then used to cast shore-normal transects at $10 \mathrm{~m}$ alongshore

221 spacing and calculate the rate of change (Net Shoreline Movement (NSM; m)) at each

222 transect intersection with the digitised shorelines. Transects where shoreline change resulted

223 in a transect crossing a creek between intersections with the two shorelines were discarded.

224 A total of 1058 transects were retained for analysis.

\section{$225 \quad 3.8 \quad$ Statistical methods}

226 The hydrodynamic forcing and the turbidity data (water level, wave activity and SSC) were

227 aggregated for each tidal inundation as well as for each sampling period of the measurements

228 on marsh and mudflat morphodynamics (Table 1). This enabled us to directly relate the

229 hydrodynamic forcing to the data collected on the morphological responses of the salt marsh

230 and the mudflat, for time periods of between 2 and 10 , but usually 5 , days.

231 The statistical analyses of the collected data included:

232 (i) Identification of drivers for intertidal sediment resuspension: (non-) linear regression 233 analysis between the median SSC (per tide) at ASM2113 and the hydrodynamic 234 forcing (table 1).

235 (ii) Comparison between landward and seaward turbidity sensors: linear regression 236 analysis between median SSC (per tide) at ASM2113 and ASM2115. 
237 (iii) Identification of drivers for the observed differences: stepwise linear regression 238 analysis with SSC difference (per tide) as the dependent variable and all variables for 239 hydrodynamic forcing (table 1) as independent variables.

240 (iv) Analysis of drivers for temporal variability of average sediment deposition on the salt 241 marsh (per sampling period): stepwise linear regression analysis with average

244 (v) Trend analysis of the spatial patterns of sediment deposition, averaged over the entire

(vi) Identification of significant trends for sediment deposition as a function of distance experiment using boxplots and the non-parametric Kruskal-Wallis test. sediment deposition as dependent variable and SSC variables (table 1) plus inundation frequency (IF) at ASM2115 as independent variables.

from the marsh edge: (a) linear regression analysis to test for a significant $(p<0.05)$ linear (positive or negative) trend; (b) nonlinear regression analysis for all insignificant periods testing for a significant (convex or concave) $2^{\text {nd }}$ order polynomial relationship.

(vii) Analysis of drivers for spatial sediment deposition patterns (as identified in (vi)): nonparametric Kruskal-Wallis test applied to all variables for hydrodynamic forcing and turbidity (table 1), categorized based on the identified spatial sediment deposition patterns.

Following every stepwise linear regression analysis, all variables included in the resulting regression models were tested for correlation (Pearson correlation coefficient). Where model variables were significantly correlated $(\mathrm{p}<0.05)$, the variable with the higher $\mathrm{p}$ value was removed from the model and the stepwise linear regression was repeated until all model variables were independent from each other. 


\section{Results}

\section{$261 \quad 4.1 \quad$ Hydrodynamic forcing}

262 The entire measurement period included seven complete spring-neap tidal cycles. These were

263 characterized by higher neap high water (HW) levels and lower spring HW levels during the

264 summer period and lower neap HW levels combined with higher spring HW levels during

265 the autumn and winter. While the seaward turbidity profiler (ASM2113) was inundated on

266 every tide, the landward profiler (ASM2115) was only inundated during tides exceeding 1.2

$267 \mathrm{~m}$ inundation depth at ASM2113. The average inundation depth at ASM2113 was $1.28 \mathrm{~m}$,

268 with a maximum of $2.13 \mathrm{~m}$ during the first tidal inundation on 17/11/2016 and a minimum

269 of $0.38 \mathrm{~m}$ during the first tide on 11/10/2016. Tidal flow velocities on the mudflat (at

270 ASM2113) were very low and could not be determined using the instrument's precision of

$271 \quad 1-2 \mathrm{~cm} \mathrm{~s}^{-1}$ and its accuracy of $0.5 \mathrm{~cm} \mathrm{~s}^{-1}$.

272 Although, the wave activity measured at ASM2113 was not correlated with the measured

273 HW levels (Pearson's $\mathrm{r}=-0.1043, \mathrm{p}=0.14$ ), the maximum wave activity appeared to be

274 related to inundation depth, with higher waves possible when inundation depths were large.

275 The upper boundary values of the measured wave proxy $\left(W P_{\max }\right)$ thereby appeared to follow

276 a linear relationship with inundation depth $(h): W P_{\max }=0.045 * h$.

277 Wave activity in summer was not significantly different (Kruskal-Wallis: $p=0.79$ ) from

278 wave activity in autumn/winter ( $W P=0.022$ in summer, compared to 0.023 in winter). The

279 maximum wave activity in summer $(W P=0.058)$ was recorded during the first tide on

$28002 / 06 / 2016$, whereas the maximum wave activity in autumn/winter $(W P=0.064)$ occurred

281 during the first tide on 20/11/2016. Sustained periods ( $>2$ days) of increased wave activity 
$282(W P>0.025)$, identified using a smoothed $W P$ time series (moving average: window size of

28310 tides), were 24/05 - 05/06/2016,03/10 - 08/10/2016, 11/10 - 16/10/2016 and 18/11 $284 \quad 28 / 11 / 2016$

285 The measured wave proxy was significantly correlated with the recorded wind speed $(v$, 286 knots) and wind direction ( $\square$ in degrees azimuth) at Shoeburyness. Higher wind speeds 287 created higher waves when blowing onshore and lower waves when blowing offshore:

289 where $m=0.000879$ is the slope and $a=0.0125$ the intersect of the linear regression between

290 the sinus-transformed wind speed (term within square brackets) and the wave proxy $\left(\mathrm{R}^{2}=\right.$ $2910.54, \mathrm{p}<0.001)$.

\section{$292 \quad 4.2$ Suspended sediment concentrations}

293 On the tidal mudflat (ASM2113) the median depth-averaged SSC ranged from 0.03 to 279 $294 \mathrm{mg} \mathrm{l}^{-1}$ in summer and from 2.6 to $1039 \mathrm{mg} \mathrm{l}^{-1}$ in autumn/winter. In both seasons SSC showed 295 a strong positive relationship with wave activity. In autumn/winter, strong wave activity had 296 a greater impact on SSC than in summer (Fig. 3). The relationship between the wave proxy 297 and the median depth-averaged SSC followed a linear trend in summer $\left(\mathrm{R}^{2}=0.72\right)$ and a 298 power function in winter $\left(\mathrm{R}^{2}=0.77\right)$ as a best fit (Fig. 3).

299 The highest SSC at ASM2113 (1039 $\left.\mathrm{mg} \mathrm{l}^{-1}\right)$ was recorded for the first tide on 22/11/2016 300 during a period of three days (20/11 - 22/11/2016) when the median SSC was greater than $301900 \mathrm{mg} \mathrm{l}^{-1}$ for every tidal inundation. During the same time period, the highest SSC was also 302 recorded at the landward turbidity profiler, located at the marsh edge (ASM2115). At this 
303 location the maximum SSC was $1445 \mathrm{mg} \mathrm{l}^{-1}$. Generally, the SSC records at ASM2113

304 (mudflat) and ASM2115 (marsh edge) were significantly correlated with each other $\left(\mathrm{R}^{2}=\right.$

$3050.83, \mathrm{p}<0.001)$. However, on average, SSC at the marsh edge was $25 \%$ higher than on the

306 mudflat (Fig. 4), indicating a general landward increase in SSC. The general trend towards a

307 landward increase in SSC was also represented in the median concentrations of 42 and 74

$308 \mathrm{mg} \mathrm{l}^{-1}$ for the sensors on the mudflat and at the marsh edge respectively.

309 The greatest difference between the landward and the seaward sensors (i.e. landward increase

310 in SSC) was observed during the first tide on 20/11/2016, when SSC at the landward sensor

311 was $519 \mathrm{mg} \mathrm{l}^{-1}$ higher than on the mudflat. Meanwhile, the largest difference for the summer

312 period was recorded for the first tide on 31/05/2016. Comparing the differences in SSC

313 between the landward (ASM2115) and the seaward (ASM2113) sensors with the

314 hydrodynamic forcing (i.e. HW level, wave proxy, depth-normalized wave proxy at

315 ASM2113), the depth-normalized wave proxy $\left(W P_{\text {norm }}\right)$ best explained the observed

316 variations $\left(\mathrm{R}^{2}=0.22, \mathrm{p}<0.0001\right)$. Moreover, the upper boundary of the landward sediment

317 transport $\left(y_{\max }\right)$ was defined by $W P_{\text {norm }}\left(y_{\max }=16000 * W P_{\text {norm }}\right)$.

\section{$318 \quad 4.3 \quad$ Sediment deposition}

\section{$319 \quad$ 4.3.1 Temporal sediment deposition pattern}

320 The average sediment deposition $(\mathrm{g})$ on all filter traps during the measurement period ranged

321 between 0.03 and $1.30 \mathrm{~g}$, averaging $0.40 \mathrm{~g}$ per sampling period. The highest sediment

322 deposition took place between 24/05 and 3/06/2016 (1.11 g) in summer and between 15/11

323 and 21/11/2016 (1.32 g) in autumn/winter. Interestingly, the sediment deposition in summer 
324 was not significantly (Kruskal-Wallis: $\mathrm{p}=0.93$ ) different from that in autumn/winter,

325 although the median and the maximum deposition were higher (Fig. 5).

326 The average sediment deposition appeared to be significantly correlated with the maximum

327 SSC at the landward sensor (ASM2115), and the number of inundations during each

328 sampling period (inundation frequency). The linear regression model including these two

329 parameters explains $69 \%$ of the observed variability in sediment deposition (Fig. 5). While

330 representing the more important driver for sediment deposition on the marsh, the maximum

$331 \mathrm{SSC}$ at ASM2115 $\left(C_{\max }\right)$ appeared to be linearly related to the maximum increase in SSC

332 between the seaward and the landward turbidity sensors (max. landward SSC increase: $C_{d i f f}$ ):

$333 C_{\max }=2.02 * C_{\text {diff }}+77.9\left(\mathrm{R}^{2}=0.66, \mathrm{p}<0.001\right)$.

\section{$334 \quad$ 4.3.2 Spatial sediment distribution pattern}

335 Averaged over the entire measurement period, the sediment deposition recorded on the filter

336 traps at the different locations within the marsh did not significantly differ between each

337 other (Kruskal-Wallis: $\mathrm{p}=0.23$ ), suggesting no systematic differences between the different

338 sites, and most importantly, no landward decrease in sediment deposition (Fig. 6).

339 The trends for sediment deposition as a function of distance from the marsh edge for every

340 sampling period individually are shown in Figure 7. A significant linear decrease from the

341 marsh edge inland was only observed between 21/11 and 26/11/2016, whereas a linear

342 increase was observed for two sampling periods (03/06 - 08/06/2016 and 10/11 -

343 15/11/2016). During four sampling periods, we found a polynomial rather than a linear

344 sedimentation pattern. The maximum sediment deposition was measured in the centre of the

345 marsh (concave polynomial pattern) during the two sampling periods 20/09 - 24/09/2016 and 
$24 / 09-04 / 10 / 2016$, whereas the minimum sediment deposition was in the centre of the

347 marsh (concave polynomial pattern) during the sampling periods 09/10 - 19/10/2016 and

$34815 / 11$ - 21/11/2016. However, for most sampling periods we could not determine any

349 significant linear or polynomial trends (Fig. 7); and the observed spatial distribution patterns

350 were not significantly related to any hydrodynamic forcing or turbidity variable (Table 1).

\section{$351 \quad 4.4 \quad$ Mudflat morphology}

352 On the mudflat, adjacent to the salt marsh, net erosion was the dominant process observed 353 during the measurement period (Fig. 8), although the difference between summer and winter 354 erosion was insignificant (Kruskal-Wallis: $\mathrm{p}=0.23$ ). However, the strongest erosion events 355 were recorded in autumn/winter, namely between $21 / 11$ and $26 / 11 / 2016(1.5 \mathrm{~cm}$, on average $)$ 356 and between $4 / 10$ and $9 / 10 / 2016$ (1.0 cm, on average). These periods coincided with the two 357 periods showing the highest average wave proxy during the entire measurement period (Fig. 358 8). Meanwhile, net sediment deposition was observed during two periods only, namely 359 between $14 / 10$ and $21 / 10 / 2016(1 \mathrm{~cm}$, on average) and between $10 / 11$ and 15/11/2016 (0.6 $360 \mathrm{~cm}$, on average). Both of these periods were characterized by relatively high maximum tidal 361 HW levels, i.e. two of the four highest inundation periods show net deposition (Fig. 8). 362 However, none of the data series for HW levels (average and maximum HW levels), wave 363 activity (average and maximum wave proxy) and sediment resuspension (average and 364 maximum SSC at ASM2113) were significantly correlated with the measured mudflat 365 erosion (Fig. 8).

\section{$366 \quad 4.5$ Surface elevation change and vertical accretion}

367 Surface elevation change over the period of our experiment was $5.6 \pm 1.5$ (1 (standard 368 deviation) $\mathrm{mm} \mathrm{yr}^{-1}$ at SET1 and ca. $5.3 \pm 2.3 \mathrm{~mm} \mathrm{yr}^{-1}$ at SET2 (Table 2: RSET rates). 
369 Meanwhile, the sediment accretion rates were $17.4 \pm 2.4$ and $9.0 \pm 2.8 \mathrm{~mm} \mathrm{yr}^{-1}$ for the marker

370 horizons $(\mathrm{MH})$ at SET1 and SET2 respectively (Table 2: MH rates). These differences

371 indicate that so-called 'shallow subsidence' (Cahoon et al., 1995), caused by sediment

372 autocompaction (i.e. difference between $\mathrm{MH}$ and RSET rate), is much higher at site SET1

373 compared to site SET2. This enhanced compaction may be related to the closer vicinity of

374 SET1 to the tidal creek network and the better drainage of the site, leading to higher

375 invertebrate activity and greater void space below the SET1 surface. Additionally, the redox

376 environments may be more favourable to decomposition of organics where oxygen

377 availability is higher. Long-term marsh edge dynamics

378 Margin retreat was found to be near-ubiquitous for the entire Dengie Peninsula with a mean 379 rate of $1.93 \mathrm{~m} \mathrm{yr}^{-1}$. For the $60 \mathrm{~m}$ of marsh margin centred on the measurement transect, the 3801992 - 2013 mean rate of retreat was $0.80 \mathrm{~m} \mathrm{yr}^{-1}$ (standard deviation $0.23 \mathrm{~m} \mathrm{yr}^{-1}$ ). The region 381 of maximum retreat (regularly exceeding $5.50 \mathrm{~m} \mathrm{yr}^{-1}$ ) was $1 \mathrm{~km}$ south of the study transect.

\section{Discussion}

\section{$383 \quad 5.1 \quad$ Drivers of intertidal sediment resuspension}

384 The supply of sediment as a vital control on the ability of coastal salt marshes to adapt to 385 rising sea levels has widely been acknowledged in previous studies (Reed, 1989; French, 386 1993; French, 2006; Blum and Roberts, 2009; Weston, 2014). This study, conducted at a 387 wave-exposed, macro-tidal coastal salt marsh on the UK east coast, shows that sediment 388 availability of salt marshes is subject to pronounced temporal variability, with major 389 variations in SSC on diurnal time scales. In contrast to systems dominated by tidal currents 390 (e.g. Scheldt estuary: Fettweis et al., 1998; Severn estuary: Allen and Duffy, 1998), sediment 391 supply on this marsh is primarily controlled by wave-induced sediment resuspension(Fig. 3), 
392 rather than resuspension caused by tidal currents, which were shown to be slower than the

393 detection limit our ADCP. Wave-induced sediment resuspension is triggered when the wave-

394 induced bed shear stress exceeds the critical bed shear stress of the mudflat surface, a

395 condition that is more likely to be met in shallow water conditions (Green and Coco, 2014).

396 In addition, the impact of wave activity on intertidal sediment resuspension varies seasonally,

397 leading to higher SSCs in winter than in summer (Temmermanet al., 2003; Poirier et al.,

398 2017). The weaker effect of wave activity on sediment resuspension during the summer

399 months (Fig. 3) is likely related to the presence of seasonal biofilms (Underwood and

400 Paterson, 1993; Paterson et al., 2000; Andersen, 2001; Tolhurst et al., 2008; Grabowski et

401 al., 2011) and/or macroalgal mats (Frostick and McCave, 1979) covering the tidal mudflat,

402 thereby reducing the erodibility of the mudflat surface.

403 Comparison of the seaward and landward turbidity during our experiment revealed a

404 landward increase in SSC, indicating sediment resuspension in the near-salt marsh margin

405 zone and subsequent landward sediment transport. This transport was significantly related to

406 the depth-normalized wave activity, suggesting that waves initiate sediment resuspension and

407 landward transport, particularly when water levels are low. Meanwhile, tidal currents appear

408 not to play a significant role in onshore sediment transport, as they are of low magnitude

409 compared to the prevailing wave activity. Similar wave-induced landward sediment transport

410 has recently been reported for the Oosterschelde, NL (Ma et al., 2018). However at other

411 sites, tidal currents have been shown to have a greater impact on landward sediment transport

412 than wave activity (Janssen-Stelder, 2000; Zhu et al., 2014). Furthermore, some studies have

413 emphasized the importance of longshore and cross-shore sediment advection for SSC and

414 tidal mudflat topography (Wang et al., 2012; Shi et al., 2016). However, these advection 
415 terms have been shown to be most pronounced in the lower (seaward) parts of tidal mudflats

416 (Le Hir et al., 2000; Wang et al., 2012), with wind and current-induced sediment resuspension

417 becoming more important towards the upper (landward) part of the tidal mudflat (Green,

418 2011; Ma et al., 2018). The latter position is where our measurements took place.

419 In previous studies, the erosion of tidal mudflats due to wave activity has widely been

420 attributed to strong wind and storm events, with calm weather periods being responsible for

421 intertidal sediment accretion, creating an equilibrium profile, adjusted to the prevailing wind

422 and tide conditions (Janssen-Stelder, 2000; Le Hir et al., 2000). The data reported here,

423 however, show little sign of elevation increases of the tidal mudflat during calm weather

424 periods, and bed level changes are not significantly related to wave activity, a finding that is

425 confirmed by recent data on mudflat elevation changes in various marsh system across the

426 North Sea (Willemsen et al., 2018). The dominant signal is one of surface lowering,

427 suggesting that the mudflat is out of equilibrium with prevailing energy conditions.

\section{$428 \quad 5.2$ Sediment deposition on the marsh surface}

429 The temporal variability of sediment deposition on the salt marsh surface was remarkably

430 well correlated with the maximum SSC at the marsh edge and the inundation frequency of

431 the marsh during each sampling period; when combined, these two variables explained $69 \%$

432 of the observed temporal variability in sediment deposition on the salt marsh. The maximum

433 SSC for each sampling period thereby appears to be more important for surface deposition

434 than the average SSC. Similar to previous studies on the vertical accretion of micro- and

435 meso-tidal marshes (Bartholdy et al., 2004; Bellucci et al., 2007; Schuerch et al., 2013), this

436 finding suggests that frequently occurring moderate to strong wind events, rather than

437 extreme events or everyday tidal inundations, primarily control salt marsh sedimentation, at 
438 least in more seaward marsh locations. By contrast, in macro-tidal marshes, extreme storm-

439 events have been shown to be more important for the vertical accretion of higher, interior 440 marsh areas (French and Spencer, 1993; van Proosdij et al., 2006).

441 Given that the maximum SSC at the marsh edge is strongly related to the maximum increase 442 in SSC between the turbidity sensors on the mudflat and at the marsh edge $\left(\mathrm{R}^{2}=0.66\right)$, the 443 majority of the sediment delivered to the salt marsh must originate from the zone extending 444 up to $130 \mathrm{~m}$ from the marsh edge, either from the tidal mudflat or the marsh edge (i.e. the 445 shore-normal ridge and runnel system) itself.. The narrowness of this zone is remarkable, 446 given that the tidal mudflat adjacent to the this part of the salt marsh extends seaward for3.7 $447 \mathrm{~km}$. The exact relative contributions of sediment supplied from the erosion of the ridge and 448 runnel system compared to sediment supplied from the erosion of the tidal mudflat cannot as 449 yet be quantified. Our data, however, indicates a contribution from both source areas.

450 The removal of sediment from this area of the tidal mudflat during increased wave activity 451 is also supported by the observed predominant lowering of the mudflat surface between the 452 seaward and the landward turbidity sensors. However, unlike earlier suggestions (Le Hir et 453 al., 2000), we show that much of this sediment is not removed from the system but 454 transported landward onto the adjacent salt marsh where it is deposited. Also, the sediment 455 seems not to originate from the marsh edge only, as previously suggested (Reed, 1988); 456 rather, the removal of the sediment actually lowers the mudflat surface.

457 The long-term measurements of sediment accretion and surface elevation change over the 458 duration of the experiment confirm that sedimentation rates at the salt marsh are high 459 compared to the long-term regional SLR rate of ca. $2.23 \mathrm{~mm} \mathrm{yr}^{-1}$ (for Sheerness (Fig. 1) 
460 during the period 1901 - 2006, reported by Woodworth et al., 2009). The salt marsh therefore

461 appears to represent a healthy tidal wetland with respect to its ability to vertically adapt to

462 rising sea levels. However, the fact that the marsh's apparent ability to adapt to SLR is due

463 to the removal of sediment from the marsh edge and the adjacent tidal mudflat in very close

464 vicinity of the salt marsh edge, shows that the marsh is less resilient to SLR than anticipated

465 from the vertical accretion rates alone (Fig. 9). As a consequence, the mudflat surface is

466 gradually being eroded, interrupted by episodic import events which (partly) replenish the

467 removed sediment with sediment from sources further offshore. This process is particularly

468 observed during periods of high HW levels and low wave activity (Fig. 8).

469 Sediment deposition on the marsh platform did not show any significant trends in relation to

470 the distance to the marsh edge. One might expect a decrease in sediment deposition rates

471 with increasing distance from the marsh edge (Christiansen et al., 2000; Temmerman et al.,

472 2003; van Proosdij et al., 2006; Poirier et al., 2017), but our data does not show any such

473 trend. Instead, the sediment that is resuspended on the tidal mudflat is distributed into the salt

474 marsh both via the marsh edge and through the complex channel network, leading to uniform

475 sediment deposition within the most seaward $47 \mathrm{~m}$ of the marsh. The distribution of

476 suspended sediment this far into the salt marsh is likely related to the wave exposure of the

477 study site, as sediment that is initially deposited on the marsh surface may be resuspended

478 and washed away during the same tide (Ma et al., 2018; Reef et al., 2018). With increasing

479 inland distance, this effect becomes weaker as wave heights and energies are rapidly reduced

480 when travelling over the vegetated marsh surface (Möller and Spencer, 2002).

$481 \quad 5.3 \quad$ Implication for long-term salt marsh morphological development 
482 Previous studies have highlighted the importance of intertidal sediment resuspension as a 483 driver for sediment availability of coastal salt marshes (Schuerch et al., 2013; Schuerch et 484 al., 2014; Ma et al., 2018) and the possibility that vertical sediment accretion may occur 485 through redistribution of sediment from the tidal mudflat and the marsh edge (Mariotti and 486 Carr, 2014). The fact that the deposited sediment is withdrawn from the marsh edge and the 487 mudflat directly adjacent to the marsh edge, however, implies a much stronger negative effect 488 of this sediment redistribution process on the overall morphological development of the salt 489 marsh, if the removed sediment is not entirely replenished (Fig. 9). The coastal slope 490 increases much faster than if the sediments were to originate from the wider tidal mudflat. 491 Such an increased coastal slope inevitably increases the wave heights of incoming waves 492 (Fagherazzi and Wiberg, 2009) and the susceptibility of the salt marsh to landward retreat 493 (Callaghan et al., 2010; Mariotti and Fagherazzi, 2010; Fig. 9).

494 Based on modelling studies, periods of lateral salt marsh erosion have been suggested either 495 as part of a cyclic behaviour of coastal salt marshes, where erosional phases are followed by 496 vegetation reestablishment and seaward expansion of the marsh (van de Koppel et al., 2005), 497 or as a transition from one stable state to another stable state, after a threshold condition has 498 been exceeded (Mariotti and Fagherazzi, 2010). These thresholds are site dependent in 499 magnitude, but usually depend on the rate of relative SLR, general sediment availability, 500 nearshore bathymetry, sediment characteristics and prevailing wind climate (Mariotti and 501 Carr, 2014).

502 In our study region (i.e. the Dengie Peninsula), a general trend of lateral marsh retreat 503 (erosion) has been reported since 1953, following an extensive period of rapid expansion 504 between 1870 and 1953 (van der Wal and Pye, 2004). The post-1953-period has been 


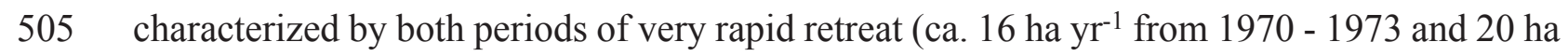

$506 \mathrm{yr}^{-1}$ from 1953-1960), times of reduced loss rates (ca. 9 ha $\mathrm{yr}^{-1}$ from 1978 and 1981 and ca.

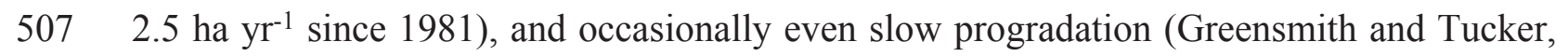

508 1965; Harmsworth and Long, 1986; Cooper et al., 2001; van der Wal and Pye, 2004).

509 Currently, our data suggest maximum marsh edge retreat rates of up to $5.5 \mathrm{~m} \mathrm{yr}^{-1}$ at the widest

510 part of the marsh, falling to $0.8 \mathrm{~m} \mathrm{yr}^{-1}$ on the transect of this experiment. Unlike the classical

511 erosion of a marsh cliff (van de Koppel et al., 2005; Marani et al., 2011), the lateral erosion

512 of this salt marsh is characterized by the erosion of the ridge-runnel system (Greensmith and

513 Tucker, 1966) as well as the seaward tidal mudflat. The formation and erosion of the ridge-

514 runnel system has been suggested to be part of the cyclic behaviour of marsh edge retreat and

515 progradation, assuming that the sediment removed from the marsh edge during lateral

516 erosion, is deposited on the tidal mudflat in front of the marsh edge, enabling the marsh to

517 re-establish once the mudflat elevation is sufficiently high (Greensmith and Tucker, 1966).

518 Our data, however, show that the majority of the sediment removed from the marsh edge and

519 the mudflat is deposited on the marsh surface, not on the tidal mudflat, suggesting that rather

520 than being a temporary erosional phase, the mudflat-salt marsh system in Tillingham is out

521 of equilibrium with the current physical setting. Based on the available data, we can therefore

522 not conclusively establish whether this instability is part of a cyclic behaviour on decadal

523 timescales or if it indicates the system's adaptation to a new equilibrium with a reduced salt

524 marsh area, in response to an environmental threshold being exceeded. Possible reasons for

525 threshold exceedance are either a reduction in the general sediment availability of the broader

526 coastal environment (e.g. reduction in riverine sediment discharge), a long-term change in

527 longshore sediment transport (e.g. due to changes in the wind/wave climate), 
528 geomorphological changes within the broader coastal shelf environment (e.g. shifting

529 subtidal sand ridges and channels in the Greater Thames estuary), or the local SLR rate

530 exceeding the ability of this system to adapt to changes in external forcing.

531 The continuous loss of salt marsh area through lateral erosion despite the high sedimentation

532 rates observed on the marsh surface highlights the close coupling of the sediment dynamics

533 on the tidal mudflat with those on the marsh surface. Salt marsh sedimentation and elevation

534 growth rates alone, often used to assess the ability of salt marshes to adapt to future SLR

535 (Webb et al., 2013), are therefore an unsuitable tool for assessing the response of a salt marsh

536 to SLR. When considering the ability of coastal salt marshes to adapt to global SLR, it is

537 therefore crucially important to not only consider the morphological development of the salt

538 marsh, but the salt marsh should also be considered as part of a coupled tidal mudflat-salt

539 marsh system.

\section{Conclusions}

541 On the Dengie Peninsula (UK), sediment availability for the vertical accretion of the marsh

542 has been shown to be highly variable in time and primarily controlled by wave activity. The

543 recorded suspended sediment concentrations are particularly high during moderate to high

544 wave events in the winter months, therefore enabling the marsh to vertically grow at a pace

545 that exceeds the long-term, regional rate of SLR. The contributed sediment, however, has

546 been shown to originate from the marsh edge and the tidal mudflat directly adjacent to the

547 salt marsh, namely within $130 \mathrm{~m}$ from the marsh edge (whereas the entire mudflat is $3.7 \mathrm{~km}$

548 wide), causing a lowering of the mudflat surface. The simultaneous increase in marsh

549 elevation and the erosion of the mudflat surface causes an increase in coastal slope and 
550 facilitates lateral marsh edge erosion, a process that has long been observed on this marsh.

551 Our results show that vertical sediment accretion and surface elevation change alone are no

552 indicators of resilience to SLR for coastal salt marshes. Rather, it is necessary to assess the

553 morphological development of the entire tidal mudflat-salt marsh system to understand how

554 resilient a coastal salt marsh really is to environmental forcing.

\section{Acknowledgments}

556 We thank Athanasios Vafeidis and Roberto Mayerle from the Christian-Albrechts-University 557 of Kiel ("The Future Ocean" Excellence Cluster) for access to field equipment. At the 558 Department of Geography, Cambridge University we thank Chris Rolfe, Steve Boreham and 559 Adam Copeland for support in conducting field and laboratory data collection; Elizabeth 560 Christie, James Tempest and Ruth Reef for help during data collection in the field; and Iris 561 Möller for her valuable comments.

\section{$562 \quad 8 \quad$ Funding}

563 This work was supported by the German Research Foundation - DFG [grant no: 272052902]

564 and by the Cambridge Coastal Research Unit (Visiting Scholar Programme to MS).

565 Additional support was received from the European Commission under the FP7 project

566 Foreshore Assessment Using Space Technology [grant no: 607131] as well as the NERC-

567 funded projects Coastal Biodiversity and Ecosystem Services Sustainability (CBESS; grant 568 no: NE/J015423/1) and BLUE-coast (grant no: NE/N015878/1).

\section{Data Availability}


570 Datasets related to this article can be found at [Link to Mendeley Data], an open-source

571 online data repository hosted at Mendeley Data

\section{$572 \quad 10 \quad$ Figure captions}

573 Figure 1: Study area. (A) Location of the study site in southeast England, on the northern 574 margin of the Greater Thames Estuary and (B) distribution of coastal salt marshes (green 575 areas) on the Essex coast, including the location of the study site (red triangle) on the salt 576 marsh near Tillingham.

577 Figure 2: Experimental design. Aerial photograph from 2016 (Environment Agency, 2016b) 578 of the studied salt marsh, the locations of the measurement devices and the topographical 579 profile of the tidal mudflat, the transition to the salt marsh and the seaward part of the 580 vegetated marsh platform, based on a $1 \mathrm{~m}$ digital terrain model (Environment Agency, 581 2016a). The seaward turbidity profiler (ASM2113) and ADCP (Nortek Aquadopp Profiler) 582 were moved from position ASM2113_a to ASM2113_b on 03/06/2016. One Solnist pressure 583 sensor was placed at each of the sites ASM2113, ASM2115/P2, P4 and SET2. The pressure

584 transducer PDCR 1830 was located in the transition zone from the tidal mudflat to the 585 vegetated salt marsh.

586 Figure 3: Intertidal sediment resuspension. Relationship between wave proxy and median 587 depth-averaged SSC. Each data point represents one tidal inundation. Data are separated 588 between summer (red squares) and autumn/winter (blue diamonds) measurements. 
589 Figure 4: Landward SSC increase. Linear relationship between depth-averaged SSC at 590 ASM2113 (mudflat) and ASM2115 (marsh edge) for the entire measurement period (summer 591 and autumn/winter).

592 Figure 5: Sediment deposition on the salt marsh. Average sediment deposition (g) of all filter 593 traps on the vegetated salt marsh (D: green bars), the maximum $\mathrm{SSC}\left(\mathrm{C}_{\max }\right.$ : brown line, in $594 \mathrm{mg} \mathrm{l}^{-1}$ ) and the inundation frequency (IF: blue stars, in tens) at ASM2115 for each sampling 595 period (2 - 10 days, but usually 5 days) between May and December 2016. No samples are 596 available for July and August. Both $\mathrm{C}_{\max }$ and IF are positively related to $\mathrm{D}: \mathrm{D}=0.00049 *$ $597 \mathrm{C}_{\max }+0.055 * \mathrm{IF}\left(\mathrm{R}^{2}=0.69, \mathrm{p}<0.001\right)$.

598 Figure 6: Spatial pattern of average sediment deposition. Boxplot of sediment deposition (g) 599 for all four filter-trap sites (P4, ASM2115, SET1 (during summer), SET2 (during 600 autumn/winter), according to the map in Fig. 2), only accounting for periods, when 601 inundation had occurred during at least one tide. Medians are represented by red lines, blue 602 boxes indicate the $25^{\text {th }}$ and $75^{\text {th }}$ percentile (Q25 and Q75). Outliers (red crosses) are values 603 larger than $\mathrm{Q} 75+1.5 *(\mathrm{Q} 75-\mathrm{Q} 25)$.

604 Figure 7: Spatial patterns of individual sediment deposition events. Sediment deposition (g) 605 from filter traps at four different locations on the salt marsh for every individual sampling 606 period. Bars are shown in the order of the site's distances to the marsh edge: ASM2115 (blue 607 bars): 0 m; P4 (orange bars): 22 m; SET1 (grey bars): 29 m; SET2 (green bars): 43 m. Error 608 bars represent the standard deviation of up to three filters deployed per site. Significant spatial 609 trends of sediment deposition are indicated by red arrows, insignificant trends by "us". 
610 Figure 8: Data time series. Time series of meteorological, hydrodynamic, SSC and mudflat 611 morphology data for the entire measurement period. Top panel: prevailing wind conditions

612 (blue: wind speed; red: onshore wind; green: offshore; black: cross-shore). $2^{\text {nd }}$ panel:

613 hydrodynamic forcing (stars: HW levels at ASM2113; crosses: HW levels at ASM2115; solid

614 line: wave proxy at ASM2113; dashed line: smoothed wave proxy (moving average: 10

615 tides). $3^{\text {rd }}$ panel: median SSC (brown squares: ASM2113; green circles: ASM2115). Bottom

616 panel: mudflat morphodynamics (bars: net erosion (negative) and deposition (positive)).

617 Figure 9: Conceptual model. Schematic view of the implications of our data for the long618 term morphological development of the salt marsh. The continuous arrow indicates the 619 primary mechanism controlling the temporal variability of sediment supply to the salt marsh, 620 dashed arrows indicate other possible mechanisms for sediment delivery, here found to be 621 insignificant and the dotted arrows indicate the occasional replenishment of the near-edge 622 tidal mudflat from either the lower tidal mudflat or external sources. The expected future 623 topography is indicated by the dashed profile line.

\section{Tables}


625 Table 1: Aggregation of high frequency raw data on hydrodynamic forcing and turbidity as

well as the morphological data on marsh and mudflat dynamics.

\begin{tabular}{|c|c|c|c|c|}
\hline \multirow{2}{*}{ 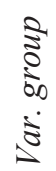 } & \multirow[b]{2}{*}{ Variable } & \multicolumn{3}{|c|}{ Level of aggregation } \\
\hline & & Raw data & Single tidal inundation & $\begin{array}{l}\text { Sampling period ( } 2 \text { - } 10 \text { days, usually } \\
5 \text { days) }\end{array}$ \\
\hline \multirow{3}{*}{ 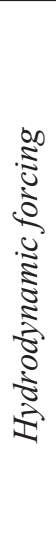 } & $\begin{array}{l}\text { Still water level } \\
\text { (ASM2113) }\end{array}$ & $\begin{array}{l}\text { Moving-average filter } \\
\text { with } 15 \text {-min window } \\
\text { size applied to raw } \\
\text { water level data }\end{array}$ & $\begin{array}{ll}\text { - } & \text { Maximum inundation } \\
& \text { depth }(\mathbf{H W} \text { level) } \\
\text { - } & \text { Tidal asymmetry (ebb } \\
& \text { / flood duration) }\end{array}$ & $\begin{array}{ll}\text { - } & \text { Mean height of HW levels (avg. } \\
& \text { HW level) } \\
\text { - } & \text { Highest HW level (max. HW level) } \\
\text { - } & \text { Inundation frequency (IF) }\end{array}$ \\
\hline & $\begin{array}{l}\text { Wave proxy } \\
\text { (ASM2113) }\end{array}$ & $\begin{array}{l}\text { Raw water level data } \\
(1 / 30 \mathrm{~Hz})\end{array}$ & $\begin{array}{l}\text { Mean deviation of raw } \\
\text { water level data from still } \\
\text { water level (Wave proxy) }\end{array}$ & $\begin{array}{ll}- & \text { Mean wave proxy (avg. WP) } \\
- & \text { Maximum wave proxy }(\max . \text { WP) }\end{array}$ \\
\hline & $\begin{array}{l}\text { Depth- } \\
\text { normalized } \\
\text { wave proxy } \\
\text { (ASM2113) }\end{array}$ & & $\begin{array}{l}\text { Wave proxy divided by } \\
\text { HW level (norm. Wave } \\
\text { proxy) }\end{array}$ & $\begin{array}{l}\text { Mean normalized wave proxy (avg. } \\
\text { norm. WP) }\end{array}$ \\
\hline \multirow{2}{*}{ 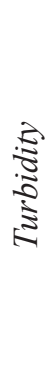 } & $\begin{array}{l}\text { Suspended } \\
\text { sediment } \\
\text { concentrations } \\
\text { (SSC) }\end{array}$ & $\begin{array}{l}\text { Depth-averaged SSC } \\
(1 / 30 \mathrm{~Hz}) \text { derived } \\
\text { from SSC profiles }\end{array}$ & $\begin{array}{l}\text { Median depth-averaged } \\
\text { SSC (median SSC) }\end{array}$ & $\begin{array}{ll}- & \text { Mean of median SSC (avg. SSC) } \\
- & \text { Maximum of median SSC (max. } \\
\text { SSC) }\end{array}$ \\
\hline & $\begin{array}{l}\text { Landward SSC } \\
\text { increase }\end{array}$ & & $\begin{array}{l}\text { Difference in median SSC } \\
\text { between the seaward and } \\
\text { the landward turbidity } \\
\text { profilers (SSC difference) }\end{array}$ & $\begin{array}{ll}\text { - } & \text { Mean SSC difference (avg. SSC } \\
\text { difference) } \\
\text { - } \\
\text { Maximum SSC difference (max. } \\
\text { SSC difference) }\end{array}$ \\
\hline \multirow{2}{*}{ 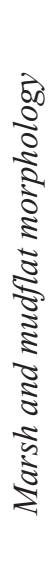 } & $\begin{array}{l}\text { Sediment } \\
\text { deposition on } \\
\text { salt marsh }\end{array}$ & $\begin{array}{l}\text { Filter trap data for } \\
\text { sampling periods } \\
\text { between } 2 \text { and } 10 \\
\text { days }\end{array}$ & & $\begin{array}{l}\text { Mean sediment deposition for each } \\
\text { site and period, including data of all } \\
\text { three traps per site (sediment } \\
\text { deposition) } \\
\text { - Mean sediment deposition of all } \\
\text { traps for one period (avg. sediment } \\
\text { deposition) }\end{array}$ \\
\hline & $\begin{array}{l}\text { Mudflat } \\
\text { morphology }\end{array}$ & $\begin{array}{l}\text { Tracer stick data for } \\
\text { sampling periods } \\
\text { between } 2 \text { and } 10 \\
\text { days }\end{array}$ & & $\begin{array}{l}\text { - Thickness of sediment on top of the } \\
\text { eroded tracer stick (top layer) } \\
\text { - Change in mudflat surface elevation } \\
\text { (erosion = initial stick length - } \\
\text { (remaining stick length + top } \\
\text { layer)) }\end{array}$ \\
\hline
\end{tabular}


627 Table 2: Long-term measurements of the increase in vertical salt marsh elevation (RSET

628 reading) and sediment accretion (MH reading) at the sites SET1 and SET2, derived from the

629 Rod Surface-Elevation Tables (RSET) and the Marker Horizons (MH), respectively.

\begin{tabular}{|c|c|c|c|c|c|c|c|}
\hline Date & Site & $\begin{array}{l}\text { RSET } \\
\text { average } \\
(\mathrm{mm})^{+}\end{array}$ & $\begin{array}{l}\text { RSET } \\
\text { std. }\end{array}$ & $\begin{array}{l}\text { SET }( \pm 1 \text { standard } \\
\text { error) rate }(\mathrm{mm} \\
\left.\mathrm{yr}^{-1}\right)\end{array}$ & $\begin{array}{l}\text { MH } \\
\text { average } \\
(\mathrm{mm})^{+}\end{array}$ & $\begin{array}{l}\text { MH } \\
\text { std. }\end{array}$ & $\begin{array}{l}\text { MH }( \pm 1 \text { standard } \\
\text { error) rate }(\mathrm{mm} \\
\left.\mathrm{yr}^{-1}\right)\end{array}$ \\
\hline $18 / 12 / 2015$ & SET1 & 0.00 & 7.86 & \multirow{3}{*}{$5.6( \pm 1.5)$} & 0.00 & 5.21 & \multirow{3}{*}{$17.4( \pm 2.4)$} \\
\hline 11/07/2016 & SET1 & 6.89 & 7.33 & & 6.83 & 7.91 & \\
\hline 17/02/2017 & SET1 & 6.64 & 6.90 & & 20.25 & 7.44 & \\
\hline $18 / 12 / 2015$ & SET2 & 0.00 & 13.51 & \multirow{3}{*}{$5.3( \pm 2.3)$} & 0.00 & 7.39 & \multirow{3}{*}{$9.0( \pm 2.8)$} \\
\hline 11/07/2016 & SET2 & 2.44 & 11.44 & & 5.42 & 6.44 & \\
\hline 17/02/2017 & SET2 & 6.19 & 9.91 & & 10.50 & 10.13 & \\
\hline
\end{tabular}

$630{ }^{+}$RSETs and MHs were installed in 2012 - readings reported here were reset to start at zero in

$631 \quad$ December 2015.

\section{References}

Allen, J.R.L., 2000. Morphodynamics of Holocene salt marshes: a review sketch from the Atlantic and Southern North Sea coasts of Europe. Quaternary Science Reviews 19, 1155 1231.

Allen, J.R.L., Duffy, M.J., 1998. Medium-term sedimentation on high intertidal mudflats and salt marshes in the Severn Estuary, SW Britain: the role of wind and tide. Marine Geology $150,1-27$.

Andersen, T.J., 2001. Seasonal Variation in Erodibility of Two Temperate, Microtidal Mudflats. Estuarine, Coastal and Shelf Science 53, 1-12.

Barbier, E.B., Hacker, S.D., Kennedy, C., Koch, E.W., Stier, A.C., Silliman, B.R., 2011. The value of estuarine and coastal ecosystem services. Ecological Monographs 81, 169-193.

Bartholdy, J., Christiansen, C., Kunzendorf, H., 2004. Long term variations in backbarrier salt marsh deposition on the Skallingen peninsula - the Danish Wadden Sea. Marine Geology 203, 1-21.

Bellucci, L.G., Frignani, M., Cochran, J.K., Albertazzi, S., Zaggia, L., Cecconi, G., Hopkins, H., 2007.210 Pb and 137Cs as chronometers for salt marsh accretion in the Venice Lagoon 
- links to flooding frequency and climate change. Journal of Environmental Radioactivity 97, 85-102.

Bergamino, L., Schuerch, M., Tudurí, A., Carretero, S., García-Rodríguez, F., 2017. Linking patterns of freshwater discharge and sources of organic matter within the Río de la Plata estuary and adjacent marshes. Marine and Freshwater Research, 68, 1704-1715.

Blum, M.D., Roberts, H.H., 2009. Drowning of the Mississippi Delta due to insufficient sediment supply and global sea-level rise. Nature Geoscience 2, 488-491.

Cahoon, D.R., Lynch, J.C., Perez, B.C., Segura, B., Holland, R.D., Stelly, C., Stephenson, C., Hensel, P., 2002. High-Precision Measurements of Wetland Sediment Elevation: II. The Rod Surface Elevation Table. Journal of Sedimentary Research 72, 734-739.

Cahoon, D.R., Reed, D.J., Day, J.W., 1995. Estimating shallow subsidence in microtidal salt marshes of the southeastern United States: Kaye and Barghoorn revisited. Marine Geology $128,1-9$.

Callaghan, D.P., Bouma, T.J., Klaassen, P., van der Wal, D., Stive, M.J.F., Herman, P.M.J., 2010. Hydrodynamic forcing on salt-marsh development: Distinguishing the relative importance of waves and tidal flows. Estuarine, Coastal and Shelf Science 89, 73-88.

Christiansen, T., Wiberg, P.L., Milligan, T.G., 2000. Flow and Sediment Transport on a Tidal Salt Marsh Surface. Estuarine, Coastal and Shelf Science 50, 315-331.

Church, J.A., Clark, P.U., Cazenave, A., Gregory, J.M., Jevrejeva, S., Levermann, A., Merrifield, M.A., Milne, G.A., Nerem, R.S., Nunn, P.D., Payne, A.J., Pfeffer, W.T., Stammer, D., Unnikrishnan, A.S., 2013. Sea Level Change, in: Stocker, T.F., Qin, D., Plattner, G.-K., Tignor, M., Allen, S.K., Boschung, J., Nauels, A., Xia, Y., Bex, V., Midgley, P.M. (Eds.), Climate Change 2013: The Physical Science Basis. Contribution of Working Group I to the Fifth Assessment Report of the Intergovernmental Panel on Climate Change. Cambridge University Press, Cambridge, United Kingdom and New York, NY, USA.

Cooper, N. J., Cooper, T., Burd, F., 2001. 25 years of salt marsh erosion in Essex: Implications for coastal defence and nature conservation. Journal of Coastal Conservation 7, 31-40.

Crosby, S.C., Sax, D.F., Palmer, M.E., Booth, H.S., Deegan, L.A., Bertness, M.D., Leslie, H.M., 2016. Salt marsh persistence is threatened by predicted sea-level rise. Estuarine, Coastal and Shelf Science 181, 93-99.

D'Alpaos, A., Lanzoni, S., Marani, M., Rinaldo, A., 2007. Landscape evolution in tidal embayments: Modeling the interplay of erosion, sedimentation, and vegetation dynamics. Journal of Geophysical Research: Earth Surface 112, F01008.

D'Alpaos, A., Mudd, S.M., Carniello, L., 2011. Dynamic response of marshes to perturbations in suspended sediment concentrations and rates of relative sea level rise. Journal of Geophysical Research: Earth Surface 116, F04020.

Environment Agency, 2016a. LIDAR Tiles Digital Terrain Model (DTM). Environment Agency. 
Environment Agency, 2016b. Vertical Aerial Photography Tiles - RGBN. Environment Agency.

Fagherazzi, S., Wiberg, P.L., 2009. Importance of wind conditions, fetch, and water levels on wave-generated shear stresses in shallow intertidal basins. Journal of Geophysical Research: Earth Surface 114, F03022.

Fettweis, M., Sas, M., Monbaliu, J., 1998. Seasonal, Neap-spring and Tidal Variation of Cohesive Sediment Concentration in the Scheldt Estuary, Belgium. Estuarine, Coastal and Shelf Science 47, 21-36.

French, J., 2006. Tidal marsh sedimentation and resilience to environmental change: Exploratory modelling of tidal, sea-level and sediment supply forcing in predominantly allochthonous systems. Marine Geology 235, 119-136.

French, J.R., 1993. Numerical simulation of vertical marsh growth and adjustment to accelerated sea-level rise, North Norfolk, U.K. Earth Surface Processes and Landforms $18,63-81$.

French, J.R., Spencer, T., 1993. Dynamics of sedimentation in a tide-dominated backbarrier salt marsh, Norfolk, UK. Marine Geology 110, 315-331.

Friedrichs, C.T., Perry, J.E., 2001. Tidal Salt Marsh Morphodynamics: A Synthesis. Journal of Coastal Research, 7-37.

Frostick, L.E., McCave, I.N., 1979. Seasonal shifts of sediment within an estuary mediated by algal growth. Estuarine and Coastal Marine Science 9, 569-576.

Grabowski, R.C., Droppo, I.G., Wharton, G., 2011. Erodibility of cohesive sediment: The importance of sediment properties. Earth-Science Reviews 105, 101-120.

Green, M.O., 2011. Very small waves and associated sediment resuspension on an estuarine intertidal flat. Estuarine, Coastal and Shelf Science 93, 449-459.

Green, M.O. and Coco, G., 2014. Review of wave-driven sediment resuspension and transport in estuaries. Reviews of Geophysics 52, 77-117.

Greensmith, J.T., Tucker, E.V., 1965. Salt Marsh Erosion in Essex. Nature 206, 606.

Greensmith, J.T., Tucker, E.V., 1966. Morphology and evolution of inshore shell ridges and mud-mounds on modern intertidal flats, near Bradwell, Essex. Proceedings of the Geologists' Association 77, 329-IN326.

Harmsworth, G.C., Long, S.P., 1986. An assessment of saltmarsh erosion in Essex, England, with reference to the Dengie Peninsula. Biological Conservation 35, 377-387.

Hill, T.D., Anisfeld, S.C., 2015. Coastal wetland response to sea level rise in Connecticut and New York. Estuarine, Coastal and Shelf Science 163, 185-193.

Janssen-Stelder, B., 2000. The effect of different hydrodynamic conditions on the morphodynamics of a tidal mudflat in the Dutch Wadden Sea. Continental Shelf Research 20, 1461-1478. 
Kirwan, M.L., Guntenspergen, G.R., D'Alpaos, A., Morris, J.T., Mudd, S.M., Temmerman, S., 2010. Limits on the Adaptability of Coastal Marshes to Rising Sea Level. Geophysical Research Letters 37, L23401.

Kirwan, M.L., Guntenspergen, G.R.C.F., 2010. Influence of tidal range on the stability of coastal marshland. Journal of Geophysical Research: Earth Surface 115, F02009.

Kirwan, M.L., Murray, A.B., 2007. A coupled geomorphic and ecological model of tidal marsh evolution. Proceedings of the National Academy of Sciences 104, 6118-6122.

Kolker, A.S., Kirwan, M.L., Goodbred, S.L., Cochran, J.K., 2010. Global climate changes recorded in coastal wetland sediments: Empirical observations linked to theoretical predictions. Geophysical Research Letters 37, L14706.

Le Hir, P., Roberts, W., Cazaillet, O., Christie, M., Bassoullet, P., Bacher, C., 2000. Characterization of intertidal flat hydrodynamics. Continental Shelf Research 20, 14331459.

Ma, Z., Ysebaert, T., Wal, D., Herman, P.M.J., 2018. Conditional effects of tides and waves on short-term marsh sedimentation dynamics. Earth Surface Processes and Landforms, Early view.

Marani, M., D'Alpaos, A., Lanzoni, S., Santalucia, M., 2011. Understanding and predicting wave erosion of marsh edges. Geophysical Research Letters 38.

Mariotti, G., Carr, J., 2014. Dual role of salt marsh retreat: Long-term loss and short-term resilience. Water Resources Research 50, 2963-2974.

Mariotti, G., Fagherazzi, S., 2010. A numerical model for the coupled long-term evolution of salt marshes and tidal flats. Journal of Geophysical Research: Earth Surface 115, F01004.

Met Office, 2006. MIDAS: UK Hourly Weather Observation Data. NCAS British Atmospheric Data Centre.

Möller, I., 2006. Quantifying saltmarsh vegetation and its effect on wave height dissipation: Results from a UK East coast saltmarsh. Estuarine, Coastal and Shelf Science 69, 337351.

Möller, I., Spencer, T., 2002. Wave dissipation over macro-tidal saltmarshes: Effects of marsh edge typology and vegetation change. Journal of Coastal Research 36, 506-521.

Möller, I., Spencer, T., French, J.R., Leggett, D.J., Dixon, M., 1999. Wave Transformation Over Salt Marshes: A Field and Numerical Modelling Study from North Norfolk, England. Estuarine, Coastal and Shelf Science 49, 411-426.

Nolte, S., Koppenaal, E.C., Esselink, P., Dijkema, K.S., Schuerch, M., De Groot, A.V., Bakker, J.P., Temmerman, S., 2013. Measuring sedimentation in tidal marshes: a review on methods and their applicability in biogeomorphological studies. Journal of Coastal Conservation 17, 301-325.

Paterson, D.M., Tolhurst, T.J., Kelly, J.A., Honeywill, C., de Deckere, E.M.G.T., Huet, V., Shayler, S.A., Black, K.S., de Brouwer, J., Davidson, I., 2000. Variations in sediment 
properties, Skeffling mudflat, Humber Estuary, UK. Continental Shelf Research 20, 13731396.

Pedersen, J.B.T., Bartholdy, J., 2006. Budgets for fine-grained sediment in the Danish Wadden Sea. Marine Geology 235, 101-117.

Poirier, E., van Proosdij, D., Milligan, T.G., 2017. The effect of source suspended sediment concentration on the sediment dynamics of a macrotidal creek and salt marsh. Continental Shelf Research 148, 130-138.

Reed, D.J., 1988. Sediment dynamics and deposition in a retreating coastal salt marsh. Estuarine, Coastal and Shelf Science 26, 67-79.

Reed, D.J., 1989. Patterns of sediment deposition in subsiding coastal salt marshes, Terrebonne Bay, Louisiana: The role of winter storms. Estuaries 12, 222-227.

Reef, R., Schuerch, M., Christie, E.K., Möller, I., Spencer, T., 2018. The effect of vegetation height and biomass on the sediment budget of a European saltmarsh. Estuarine, Coastal and Shelf Science 202, 125-133.

Rodríguez, J.F., Saco, P.M., Sandi, S., Saintilan, N., Riccardi, G., 2017. Potential increase in coastal wetland vulnerability to sea-level rise suggested by considering hydrodynamic attenuation effects. Nature Communications 8, 16094.

Runte, K., 1989. Methodische verfahren zur quantifizierung von umlagerungen in intertidalen sedimenten. Meyniana 41, 153-165.

Schepers, L., Kirwan, M., Guntenspergen, G., Temmerman, S., 2017. Spatio-temporal development of vegetation die-off in a submerging coastal marsh. Limnology and Oceanography 62, 137-150.

Schuerch, M., Dolch, T., Reise, K., Vafeidis, A.T., 2014. Unravelling interactions between salt marsh evolution and sedimentary processes in the Wadden Sea (southeastern North Sea). Progress in Physical Geography: Earth and Environment 38, 691-715.

Schuerch, M., Spencer, T., Temmerman, S., Kirwan, M.L., Wolff, C., Lincke, D. McOwen, C.J., Pickering, M.D., Reef, R., Vafeidis, A.T., Hinkel, J, Nicholls, R.J., Brown, S., 2018. Future response of global coastal wetlands to sea level rise. Nature 561, 231-234. Schuerch, M., Scholten, J., Carretero, S., García-Rodríguez, F., Kumbier, K., Baechtiger, M., Liebetrau, V., 2016. The effect of long-term and decadal climate and hydrology variations on estuarine marsh dynamics: An identifying case study from the Río de la Plata. Geomorphology 269, 122-132.

Schuerch, M., Vafeidis, A., Slawig, T., Temmerman, S., 2013. Modeling the influence of changing storm patterns on the ability of a salt marsh to keep pace with sea level rise. Journal of Geophysical Research: Earth Surface 118, 84-96.

Schwarzer, K., Diesing, M., Larson, M., Niedermeyer, R.O., Schumacher, W., Furmanczyk, K., 2003. Coastline evolution at different time scales - examples from the Pomeranian Bight, southern Baltic Sea. Marine Geology 194, 79-101.

Shi, B., Wang, Y.P., Du, X., Cooper, J.R., Li, P., Li, M.L., Yang, Y., 2016. Field and theoretical investigation of sediment mass fluxes on an accretional coastal mudflat. Journal of Hydro-environment Research 11, 75-90. 
Spencer, T., Schuerch, M., Nicholls, R.J., Hinkel, J., Lincke, D., Vafeidis, A.T., Reef, R., McFadden, L., Brown, S., 2016. Global coastal wetland change under sea-level rise and related stresses: The DIVA Wetland Change Model. Global and Planetary Change 139, $15-30$.

Stevenson, J.C., Ward, L.G., Kearney, M.S., 1986. Vertical accretion in marshes with varying rates of sea level rise, in: Wolfe, D.A. (Ed.), Estuarine Variability. Academic Press Inc., Orlando, Florida, pp. 241-259.

Temmerman, S., Govers, G., Meire, P., Wartel, S., 2003. Modelling long-term tidal marsh growth under changing tidal conditions and suspended sediment concentrations, Scheldt estuary, Belgium. Marine Geology 193, 151-169.

Temmerman, S., Govers, G., Wartel, S., Meire, P., 2003. Spatial and temporal factors controlling short-term sedimentation in a salt and freshwater tidal marsh, Scheldt estuary, Belgium, SW Netherlands. Earth Surface Processes and Landforms 28, 739-755.

Thieler, E.R., Himmelstoss, E.A., Zichichi, J.L., Ergul, A., 2009. The Digital Shoreline Analysis System (DSAS) Version 4.0 - An ArcGIS extension for calculating shoreline change, Open-File Report, - ed, Reston.

Tolhurst, T.J., Consalvey, M., Paterson, D.M., 2008. Changes in cohesive sediment properties associated with the growth of a diatom biofilm. Hydrobiologia 596, 225-239.

Towler, P., Fishwick, M., 2017. Reeds Nautical Almanac 2018. Bloomsbury Publishing Plc, London.

Underwood, G.J.C., Paterson, D.M., 1993. Seasonal changes in diatom biomass, sediment stability and biogenic stabilization in the Severn Estuary. Journal of the Marine Biological Association of the United Kingdom 73, 871-887.

van de Koppel, J., van der Wal, D., Bakker, J.P., Herman, P.M.J., 2005. Self-Organization and Vegetation Collapse in Salt Marsh Ecosystems. The American Naturalist 165, E1E12.

van der Wal, D., Pye, K., 2004. Patterns, rates and possible causes of saltmarsh erosion in the Greater Thames area (UK). Geomorphology 61, 373-391.

van Proosdij, D., Davidson-Arnott, R.G.D., Ollerhead, J., 2006. Controls on spatial patterns of sediment deposition across a macro-tidal salt marsh surface over single tidal cycles. Estuarine, Coastal and Shelf Science 69, 64-86.

Wang, Y.P., Gao, S., Jia, J., Thompson, C.E.L., Gao, J., Yang, Y., 2012. Sediment transport over an accretional intertidal flat with influences of reclamation, Jiangsu coast, China. Marine Geology 291-294, 147-161.

Webb, E.L., Friess, D.A., Krauss, K.W., Cahoon, D.R., Guntenspergen, G.R., Phelps, J., 2013. A global standard for monitoring coastal wetland vulnerability to accelerated sealevel rise. Nature Climate Change 3, 458-465.

Weston, N.B., 2014. Declining Sediments and Rising Seas: an Unfortunate Convergence for Tidal Wetlands. Estuaries and Coasts 37, 1-23. 
844 Willemsen, P.W.J.M., Borsje, B.W., Hulscher, S.J.M.H., van der Wal, D., Zhu, Z., Oteman, 845 B., Evans, B., Möller, I., Bouma, T.J., 2018. Quantifying Bed Level Change at the 846 Transition of Tidal Flat and Salt Marsh: Can We Understand the Lateral Location of the 847 Marsh Edge? Journal of Geophysical Research: Earth Surface 123. [doi: $848 \quad 10.1029 / 2018 J F 004742]$

849 Woodworth, P.L., Teferle, F.N., Bingley, R.M., Shennan, I., Williams, S.D.P., 2009. Trends 850 in UK mean sea level revisited. Geophysical Journal International 176, 19-30.

851 Zhou Z., Ye Q., Coco G., 2016. A one-dimensional biomorphodynamic model of tidal flats: 852 Sediment sorting, marsh distribution, and carbon accumulation under sea level rise. 853 Advances in Water Resources 93, 288-302.

854 Zhu, Q., Yang, S., Ma, Y., 2014. Intra-tidal sedimentary processes associated with combined 855 wave-current action on an exposed, erosional mudflat, southeastern Yangtze River Delta, $856 \quad$ China. Marine Geology 347, 95-106. 


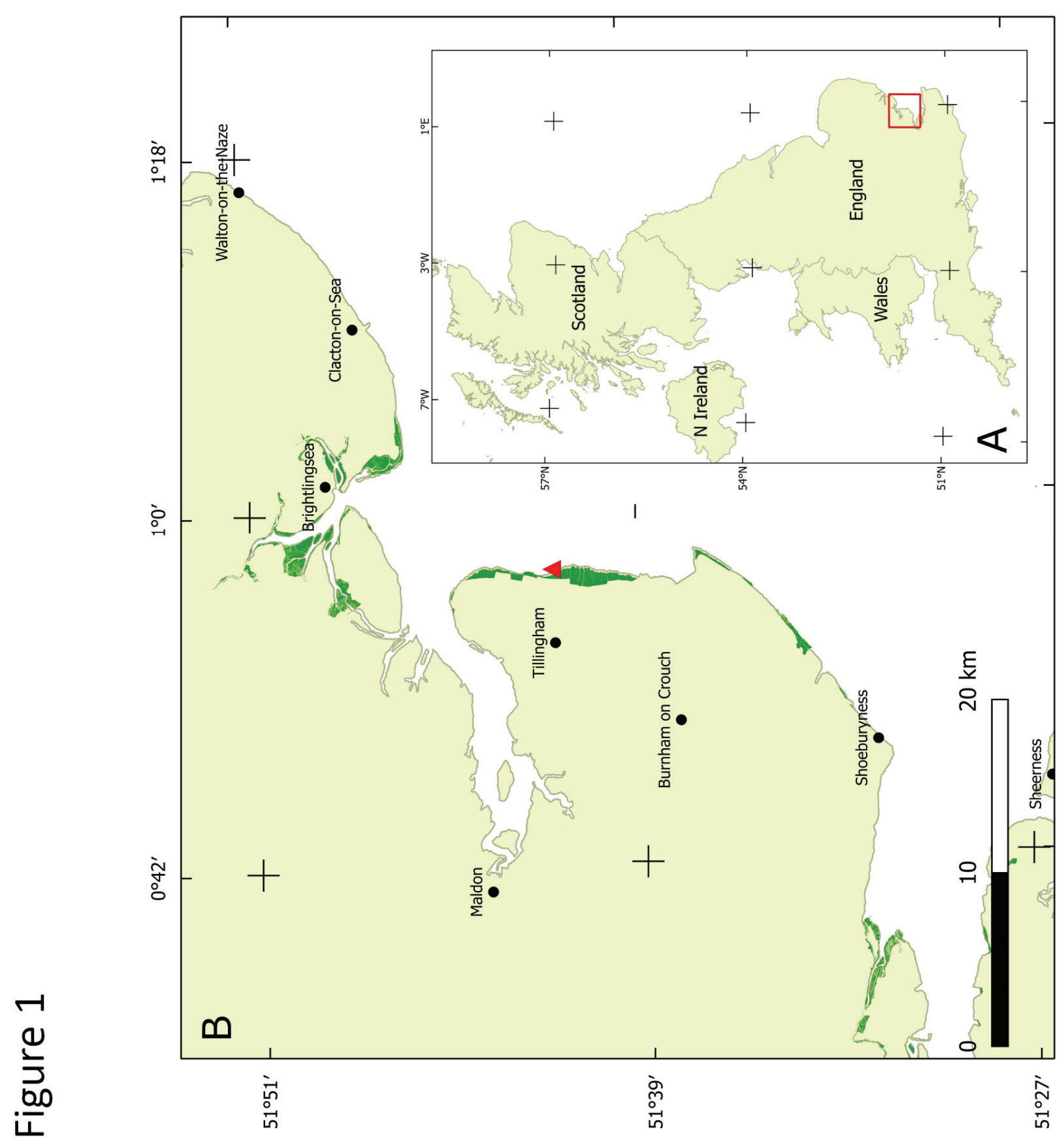




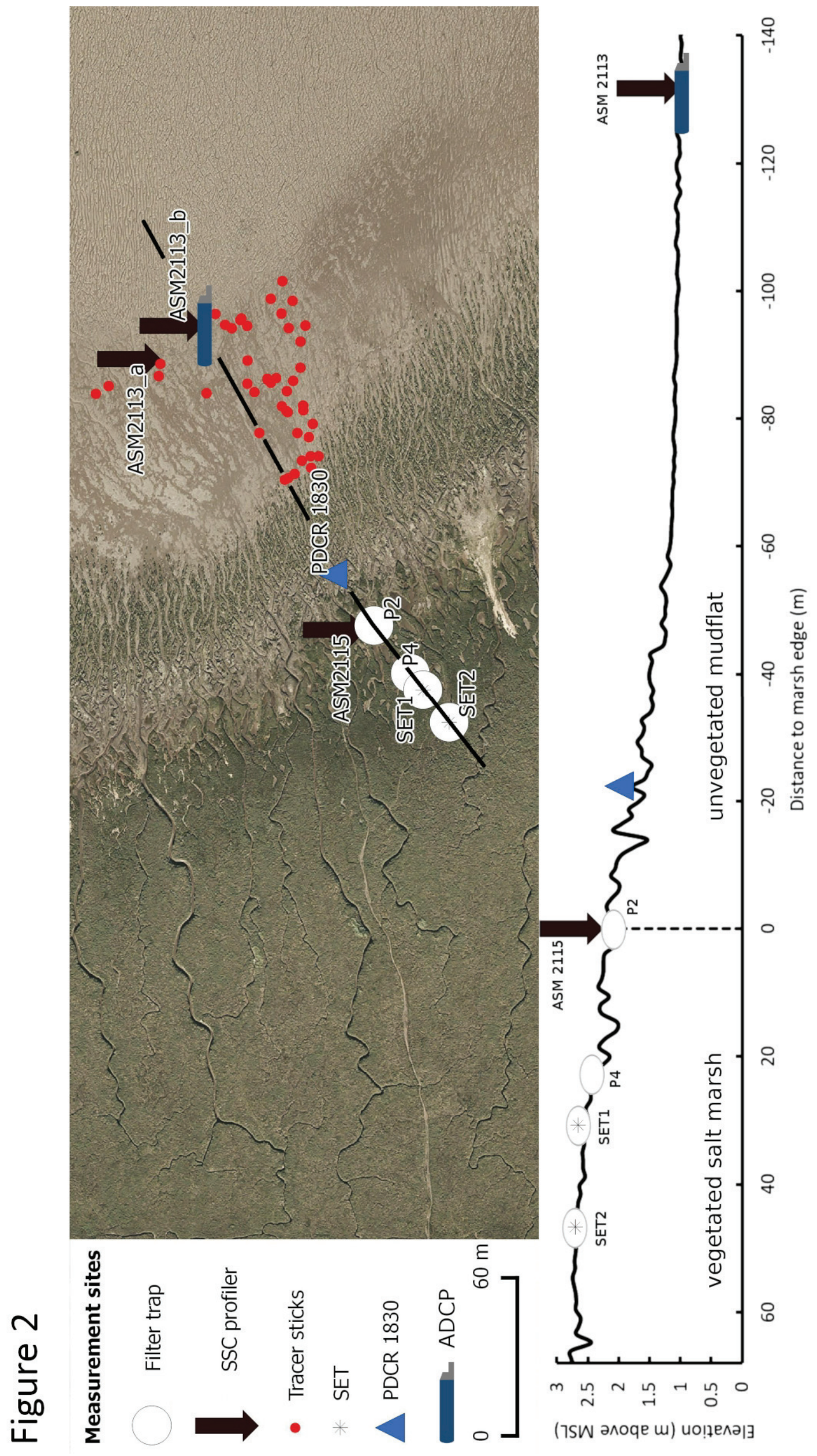




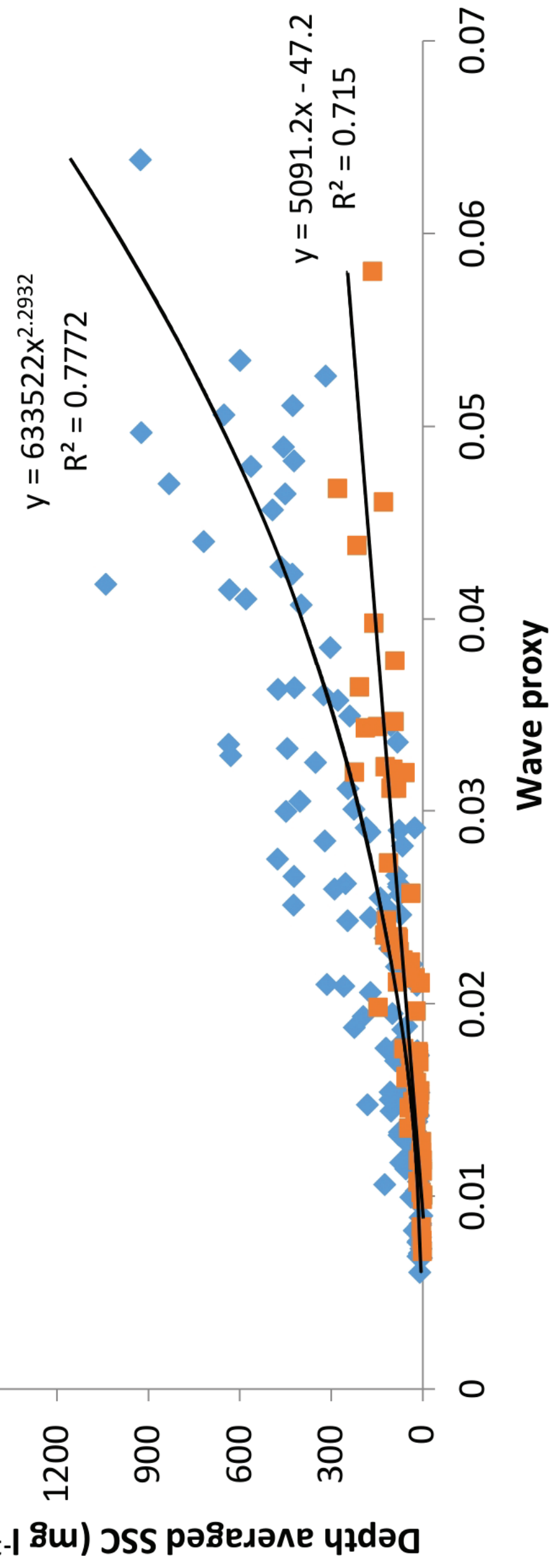




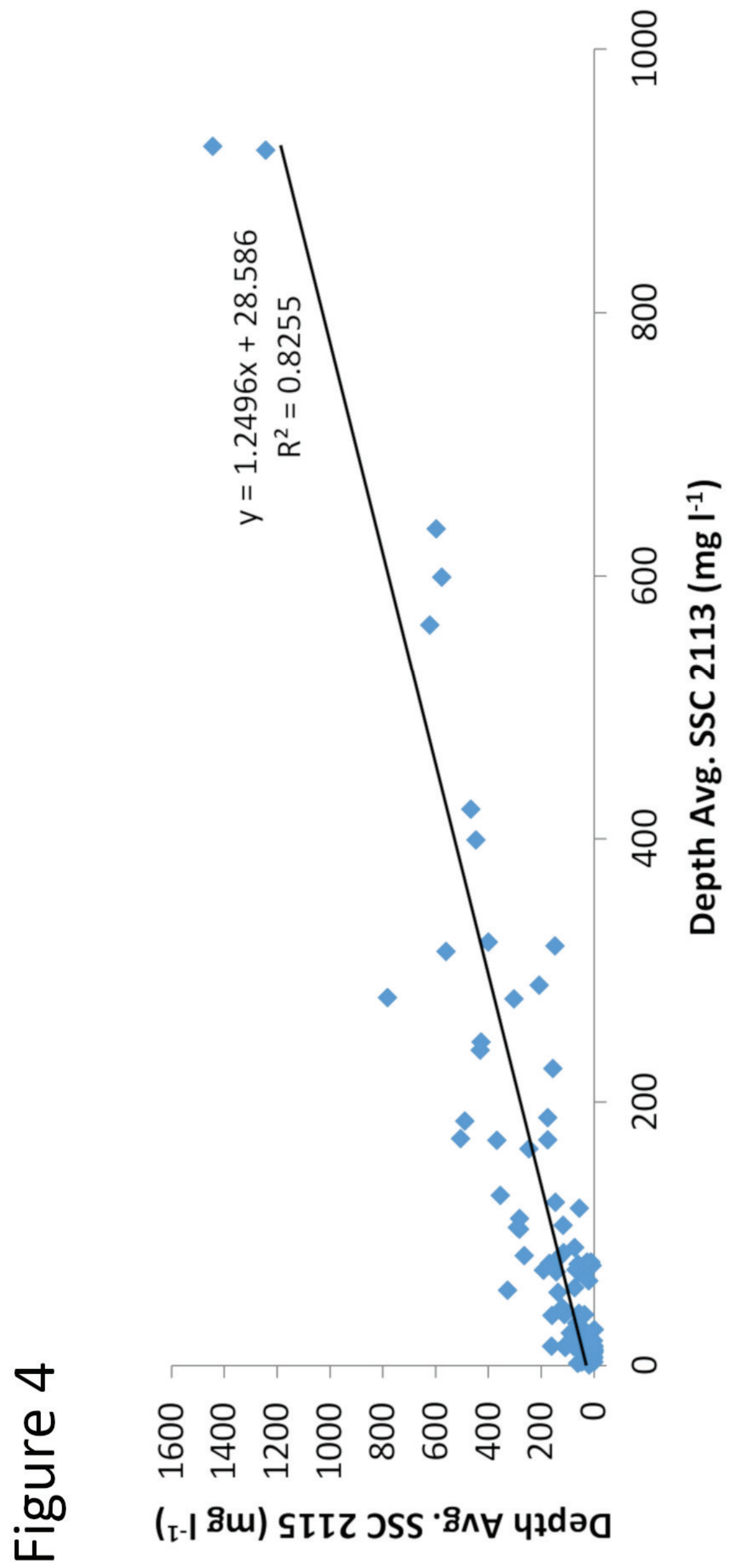




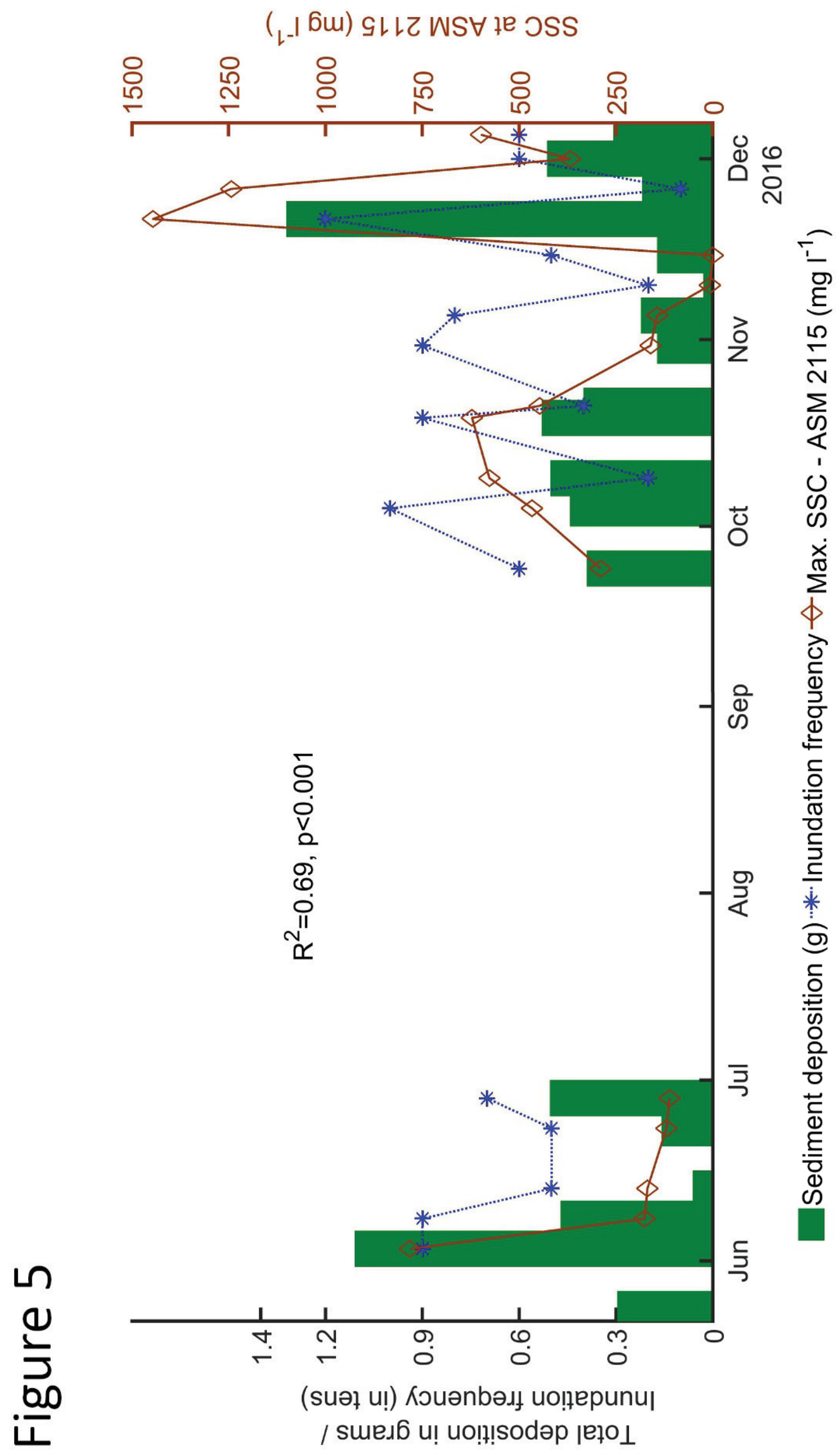




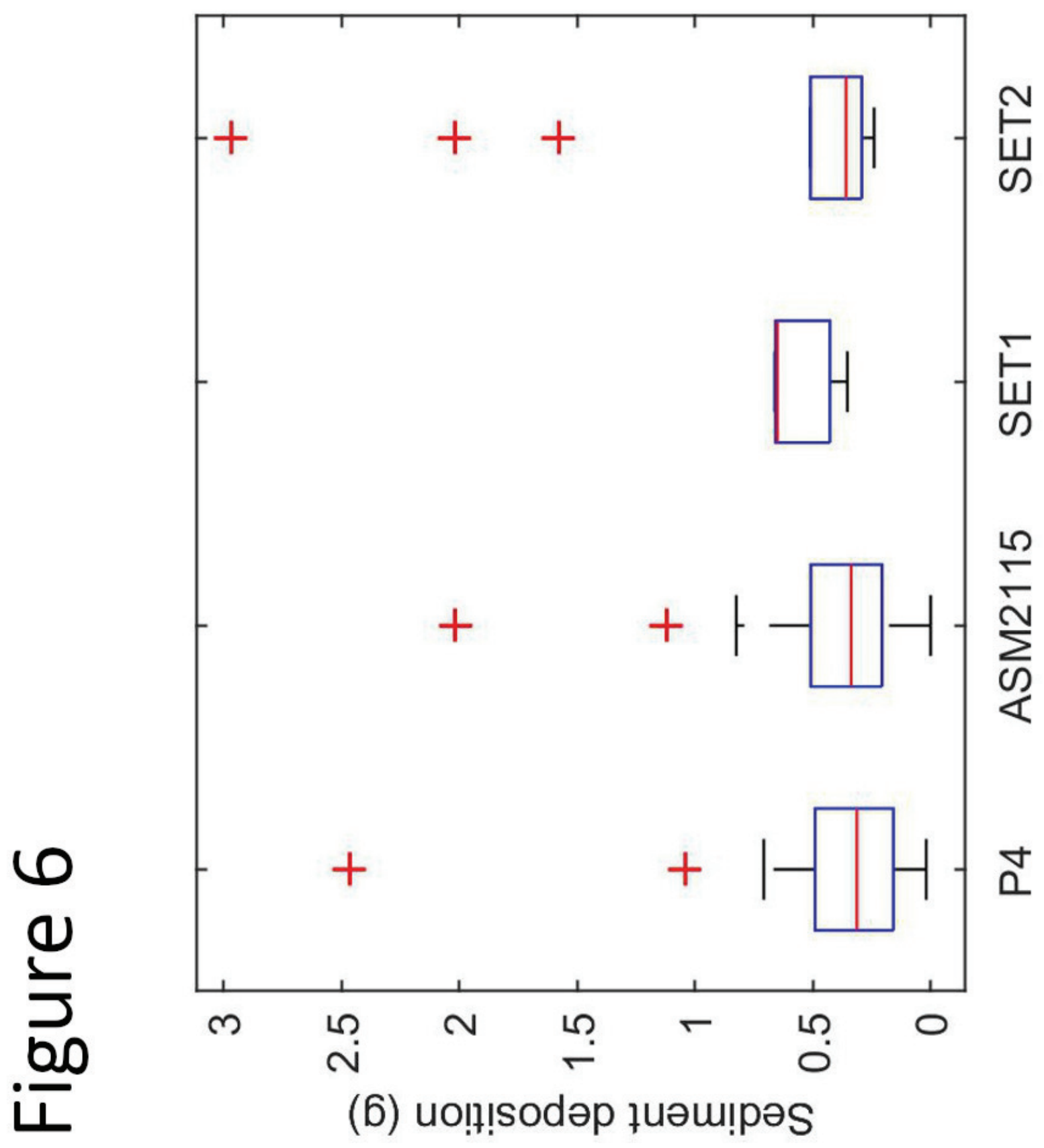




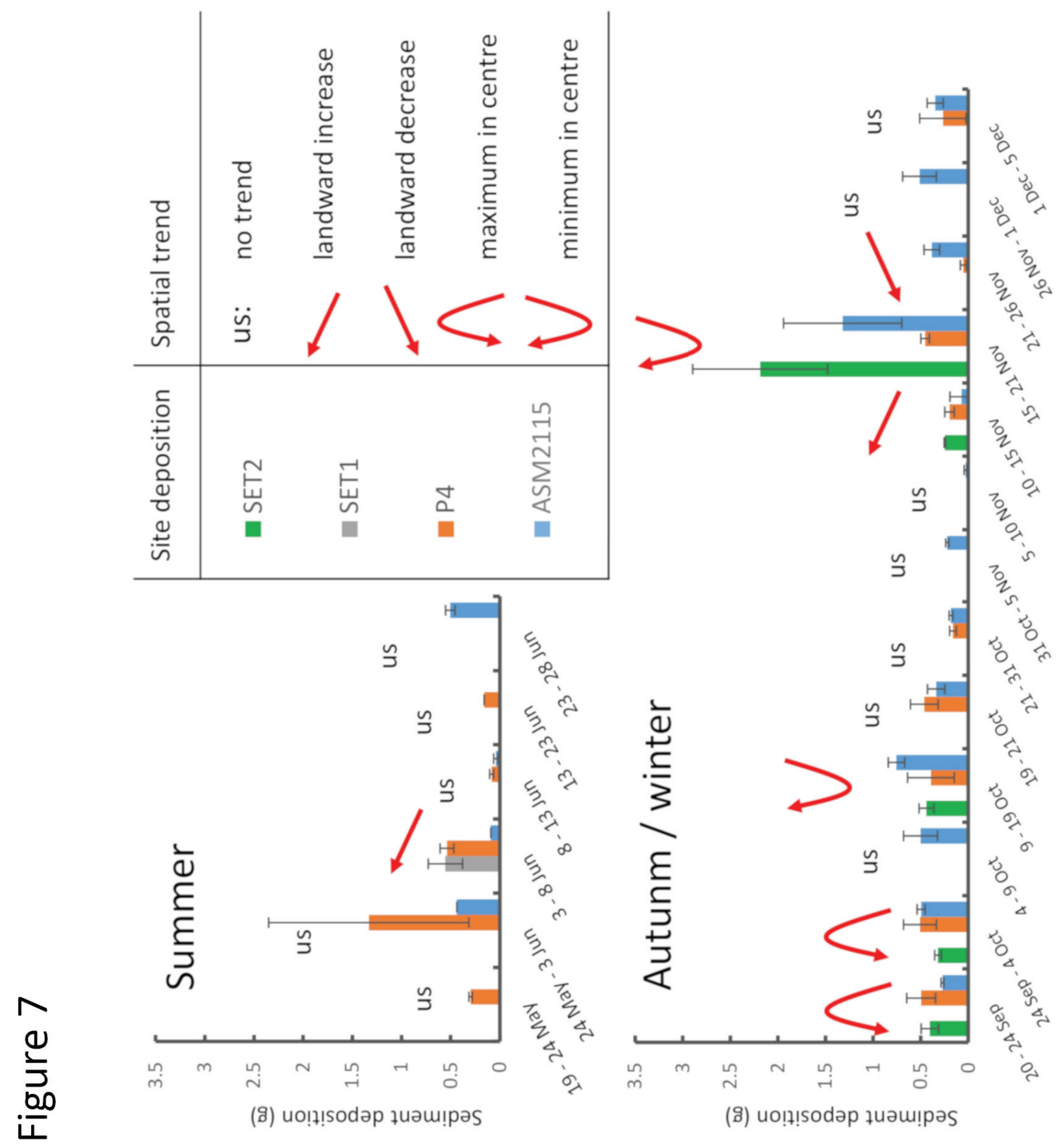



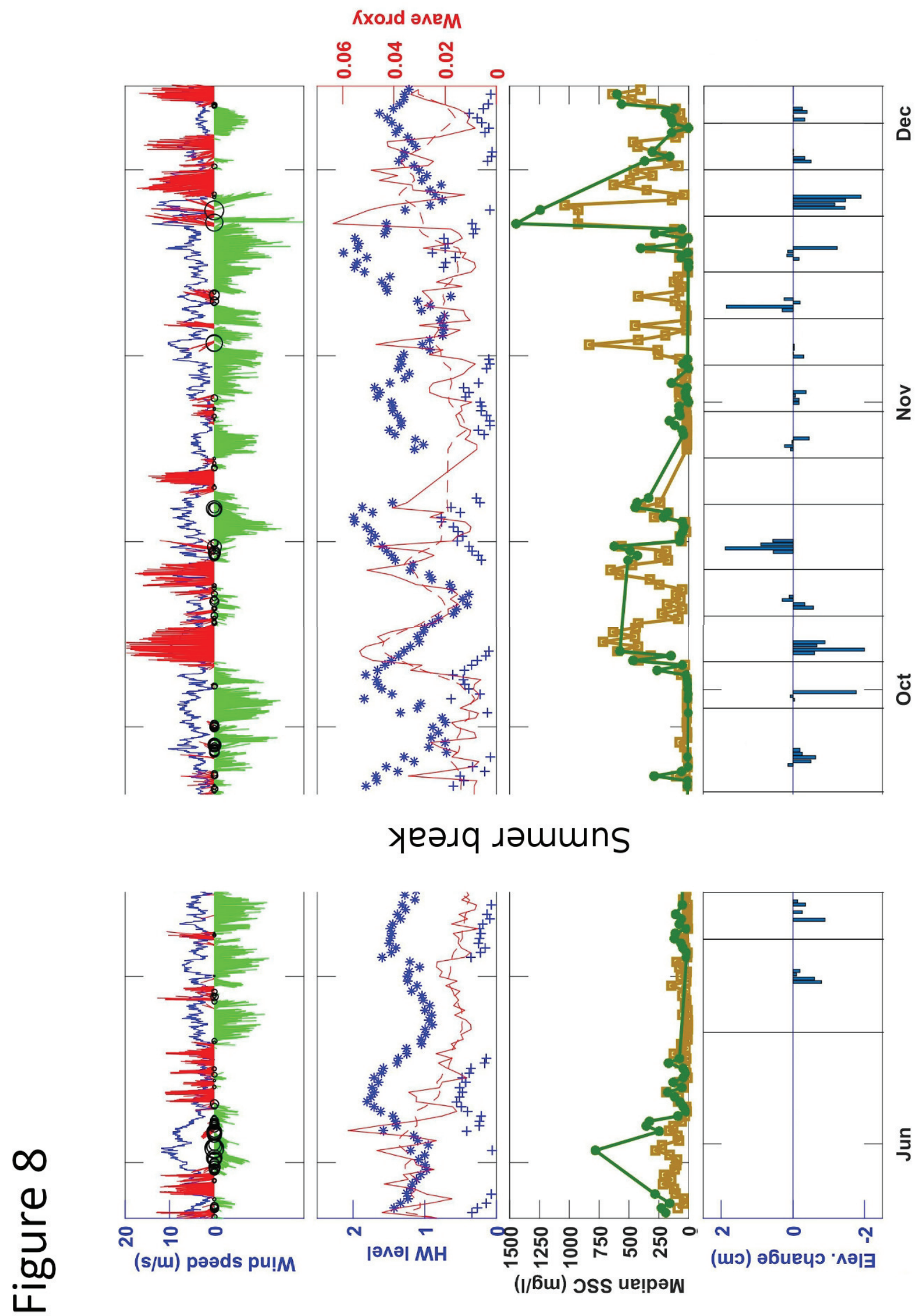


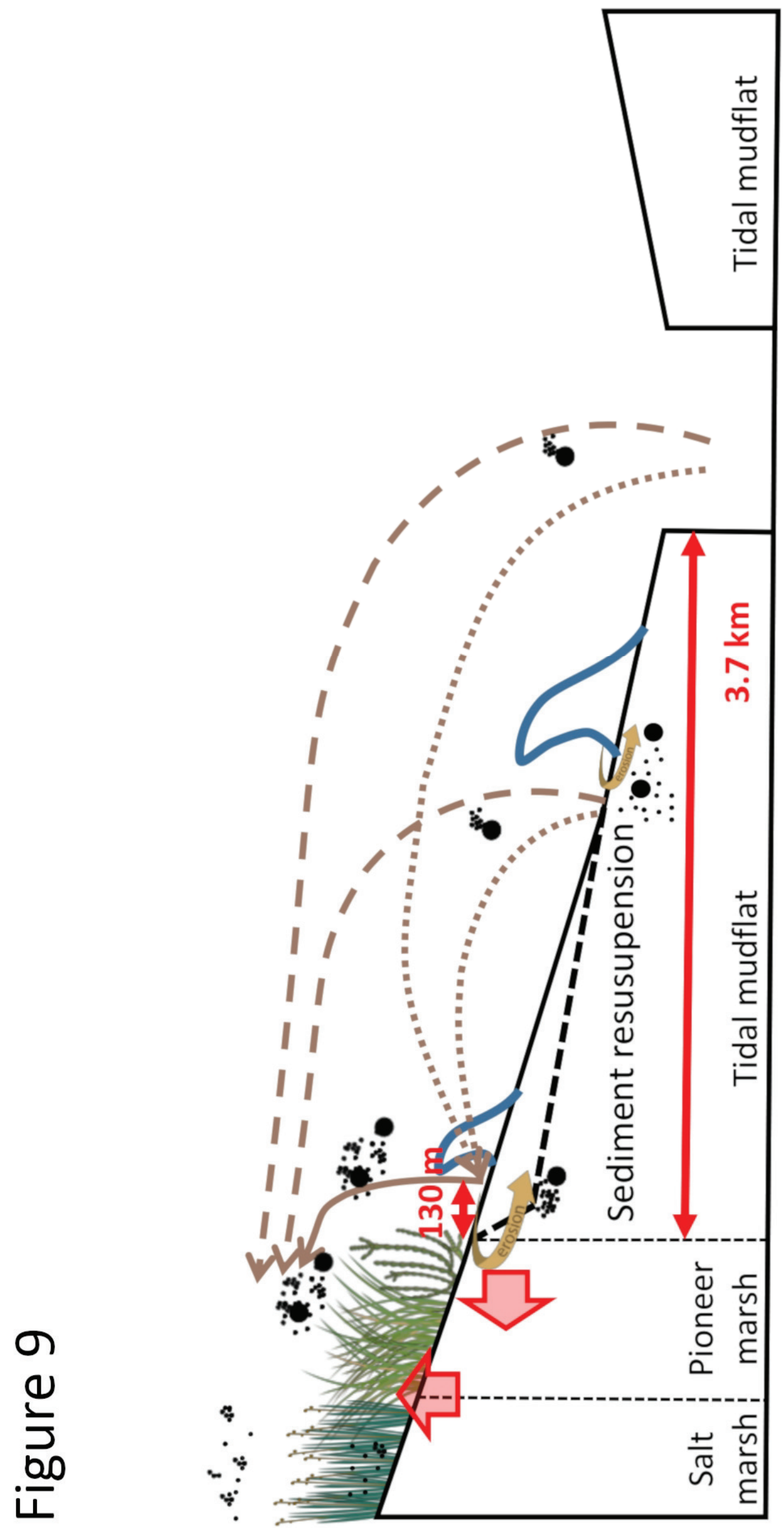

